\title{
LCA of biomass-based energy systems
}

a case study for Denmark

\section{Tonini, Davide; Astrup, Thomas Fruergaard}

\section{Published in:}

Applied Energy

Link to article, DOI:

10.1016/j.apenergy.2012.03.006

Publication date:

2012

Document Version

Peer reviewed version

Link back to DTU Orbit

Citation (APA):

Tonini, D., \& Astrup, T. F. (2012). LCA of biomass-based energy systems: a case study for Denmark. Applied Energy, 99, 234-246. https://doi.org/10.1016/j.apenergy.2012.03.006

\section{General rights}

Copyright and moral rights for the publications made accessible in the public portal are retained by the authors and/or other copyright owners and it is a condition of accessing publications that users recognise and abide by the legal requirements associated with these rights.

- Users may download and print one copy of any publication from the public portal for the purpose of private study or research.

- You may not further distribute the material or use it for any profit-making activity or commercial gain

- You may freely distribute the URL identifying the publication in the public portal

If you believe that this document breaches copyright please contact us providing details, and we will remove access to the work immediately and investigate your claim 


\title{
LCA of biomass-based energy systems: A case study for Denmark
}

\author{
Tonini, $D .{ }^{*} \&$ Astrup, $T$. \\ Department of Environmental Engineering - Technical University of Denmark \\ DTU-Building 115, DK-2800 Kgs. Lyngby, Denmark \\ *Corresponding author: Davide Tonini \\ E-mail: dait@env.dtu.dk
}

\section{Accepted version of the manuscript:}

Tonini D, Astrup T. Life-cycle assessment of biomass-based energy systems: A case study for Denmark. Appl Energy 2012;99:234-46.

This version did not undergo proof-reading and final journal editing. When referring to this work, please cite the journal publication stated above. 


\begin{abstract}
Decrease of fossil fuel consumption in the energy sector is an important step towards more sustainable energy production. Environmental impacts related to potential future energy systems in Denmark with high shares of wind and biomass energy were evaluated using life-cycle assessment (LCA). Based on the reference year 2008, energy scenarios for 2030 and 2050 were assessed. For 2050 three alternatives for supply of transport fuels were considered: 1) fossil fuels, 2) rapeseed based biodiesel, and 3) Fischer-Tropsch based biodiesel. Overall, the results showed that greenhouse gas emissions per PJ energy supplied could be reduced by more than half by increased use of wind and residual biomass resources as well as by electrifying the transport sector (from 68 to $17 \mathrm{Gg} \mathrm{CO}_{2}$ eq/PJ). Energy crops for production of biofuels and the use of these biofuels for heavy terrestrial transportation were responsible for most environmental impacts in the 2050 scenarios, in particular upstream impacts from land use changes (LUC), fertilizer use, and $\mathrm{NO}_{\mathrm{x}}$ emissions from the transport sector were critical. Land occupation (including LUC effects) caused by energy crop production increased to a range of $600-210010^{6} \mathrm{~m}^{2} / \mathrm{PJ}$ depending on the amounts and types of energy crops introduced. Use of fossil diesel in the transport sector appeared to be environmentally preferable over biodiesel for acidification, aquatic eutrophication, and land occupation. For global warming, biodiesel production via Fischer-Tropsch was comparable with fossil diesel.
\end{abstract}

Keywords: LCA, LUC, biomass potential, energy system analysis, biodiesel, environmental impacts

\title{
1. Introduction
}

In many countries, considerable efforts have been made to reduce greenhouse gas (GHG) emissions within the energy sector as part of the response to climate changes. Within the recent decades, Denmark has managed to control the energy demand which today is similar to that before the oil crisis in the 1970s (864 PJ). In 2008, the share of fossil fuels in the energy system corresponded to about $84 \%$ (of the primary energy supply). The share of oil corresponded to 39\%. Overall, about $16 \%$ of the primary energy supply was based on renewables such as biomass, solar energy and waste resources [1] (for instance, 
about $20 \%$ of the electricity production was based on wind). The long-term political target for Denmark is to reach a 100\% renewable energy system in 2050 primarily based on wind power and biomass energy but also involving significant decreases in the national energy demand [2]. Several studies have modeled future sustainable energy systems from a technical perspective [3-12]. According to these studies, 100\% renewable energy systems can only realistically be achieved through significant reductions in energy demand, increased efficiencies of fuel conversion technologies, higher shares of wind power (e.g. up to 50\%), replacement of fossil fuels with biomass resource and integration of the transport sector into the energy system, e.g. through establishment of electric vehicles $[13,14]$. Although the primary focus of studies involving energy system analysis is on the technical design of the energy system (modeling of energy demand and supply, fuels requirements, and technology implementation), many of these studies also report associated $\mathrm{CO}_{2}$ emissions as an indicator for the environmental impacts related to the energy system in question. However, such calculations of direct emissions associated with the combustion of fuels do not account for important upstream or downstream environmental impacts related to the energy system, for example land use changes (LUC, due to energy crops cultivation), cascading effects (e.g. substitution of products in the market with byproducts from biofuel production), and utilization of residues (e.g. digestate and biochar).

GHG emissions have received considerable attention recently; however, other potential environmental impacts are associated with energy production (e.g. eutrophication, acidification and land use). Such impacts are typically not considered by energy system analysis. To provide a full overview of the environmental consequences of changing energy production in the future, all upstream, direct and downstream emissions have to be accounted in a life-cycle perspective. We have found no such studies in the literature focusing on energy systems with high shares of wind and biomass energy.

This study quantifies the environmental impacts associated with potential future energy scenarios for Denmark in 2030 and 2050. These future scenarios are compared with the existing energy system in the reference year 2008. Environmental impacts were quantified using life-cycle assessment (LCA). All relevant energy technologies and conversion processes in the energy system were addressed (e.g. wind energy, 
hydropower, photovoltaic, solar heating and Biomass-to-Energy (BtE) technologies); however, particular focus was placed on the Biomass-to-Energy subsystems as biomass and associated land use effects were a specific concern.

The specific objectives were: i) identification of potential biomass resources, ii) identification and selection of suitable biomass conversion technologies and related efficiencies, and iii) quantification of environmental impacts associated with the selected energy systems.

\section{Methodology}

\subsection{Goal, scope and functional unit}

The goal of the LCA was to assess the environmental impacts related to more sustainable energy scenarios in Denmark. A range of potentially future energy scenarios were selected based on a mix of residual agricultural resources, energy crops, wind and other renewables (e.g. waves and solar heating) and to the extent needed also fossil fuels. All future energy scenarios were compared with a reference representing the Danish energy system in 2008. The service defined by the LCA functional unit was "meeting the energy demand (electricity, heat and fuels) required in Denmark in the years 2008, 2030 and 2050". This service does not describe the amount of energy provided, but it is defined to ensure that the future living standards are similar to the 2008 baseline. As the modeled energy demand and supply was not identical in the selected scenarios, the LCA modeling results were normalized with the primary energy supply (named 'PES') for the individual years to allow comparison. This provided the intensity of the environmental impact per unit of primary energy supplied (e.g. $\mathrm{Gg} \mathrm{CO}_{2}$-eq/PJ $/ \mathrm{PES}_{\mathrm{PES}}$ to the system and allowed comparison of the energy systems in spite of the different energy demands. For example, a decrease in environmental impact should be equal to or be larger than a decrease in supply in order to achieve an overall lower 'normalized' impact. The environmental impacts were quantified with a time horizon of 100 years according to common LCA practice [15].

\subsection{Assessment approach}


The overall approach used for carrying out the life-cycle assessment included the following steps: 1) selection of potential energy scenarios based on available national energy strategies and political targets (e.g. regarding shares of wind power, $\mathrm{CO}_{2}$ emission reductions, etc.), 2) selection of relevant conversion technologies and collection of associated technology data for the LCA, 3) balancing energy supply and demand for each scenario to provide the necessary input for the LCA, 4) performance of the impact assessment and discussion of results.

Step (1) above was carried out based on energy system analysis of future $100 \%$ renewable Danish energy systems performed in separate studies using the model EnergyPLAN [4-6,16]. Therefore, detailed documentation of the technical properties of the selected energy scenarios was outside the scope of this paper but can be found in the cited references.

\subsection{Impact assessment}

The life-cycle assessment was carried out according to the EDIP2003 methodology [17] for the environmental impact categories: global warming, acidification and aquatic eutrophication (distinguishing was made between nitrogen and phosphorous related impacts). Impacts related to land occupation was included in the assessment according to the IMPACT2002+ methodology for this impact category [18]. For acidification, the results were expressed as area of unprotected ecosystem within the full deposition area that is brought to exceed the critical load of acidification as a consequence of the emissions (unit: $10^{4} \mathrm{~m}^{2} / \mathrm{PJ} \mathrm{PES}$ ). Site-generic characterization factors (average values for EU15 plus Switzerland and Norway) were used [17]. Site-dependent characterization factors were only available for a few compounds and the values were very similar to the site-generic factors for Denmark. Particularly, for $\mathrm{SO}_{2}, \mathrm{NO}_{\mathrm{x}}$ and $\mathrm{NH}_{3}$ the site-generic characterization factors were 17.7, 8.6 and $23 \mathrm{~m}^{2}$ of unprotected ecosystem $/ \mathrm{kg}$. For aquatic eutrophication, two sub-categories were used according to the methodology: aquatic eutrophication (nitrogen) where impacts are expressed as $\mathrm{kg} \mathrm{N} / \mathrm{PJ}_{\mathrm{PES}}$ and aquatic eutrophication (phosphorous) where impacts are expressed as $\mathrm{kg} \mathrm{P} / \mathrm{PJ} \mathrm{JEs}_{\mathrm{PE}}$. The emissions of $\mathrm{N}$ and $\mathrm{P}$ are accounted separately because there are aquatic ecosystems where the limiting nutrient is $\mathrm{P}$ (typically inland waters in EU temperate regions, e.g. lakes) and 
others where $\mathrm{N}$ is the limiting nutrient (e.g. marine waters). The relevant characterization factors for aquatic eutrophication were: $0.096 \mathrm{~kg} \mathrm{~N} / \mathrm{kg} \mathrm{NO}_{\mathrm{x}}, 0.1886 \mathrm{~kg} \mathrm{~N} / \mathrm{kg} \mathrm{NH}_{3}, 0.29$ $\mathrm{kg} \mathrm{P} / \mathrm{kg} \mathrm{PO}_{4}{ }^{3-}$ (emitted to water), and $0.88 \mathrm{~kg} \mathrm{P} / \mathrm{kg} \mathrm{P}$ (emitted to water).

For multiple-output processes such as biorefineries, where valuable byproducts (e.g. fodder or chemicals) were generated together with fuels, system expansion was applied and it was assumed that these products substituted the marginal products in the market, according to the principles of consequential LCA [19]. The life-cycle assessment was facilitated by the LCA software Simapro 7.1 [20]. The energy balances (Figure 1-3) were facilitated by the software STAN [21].

\section{Table 1}

Table 2

\subsection{Energy scenarios}

Five different energy scenarios were assessed: I) “2008” (reference), II) “2030”, III) “2050CSV” (2050 conservative (CSV) scenario), IV) “2050RME” (2050 scenario where biodiesel as rape methyl ester (RME) is totally produced from rapeseed) and V) "2050BtL” (2050 scenario where biodiesel (FT-biodiesel) is produced from lignocellulosic biomass through Biomass-to-Liquid (BtL) and Fischer-Tropsch (FT) technology, except for the share of RME corresponding to the amount produced today in DK). The latter three represented different potential alternatives for transport fuel production in year 2050 .

\section{Scenario}

The “2008” scenario was selected as reference representing the current energy system primarily based on fossil resources. Data for energy demand and supply were based on Danish national statistics for 2008 [22]: the gross primary energy supply was 864 PJ while the final net consumption by society was 652 PJ (excluding transmission losses). An overview of the energy scenario "2008” is shown in Fig. 1. 
Energy scenarios representing 2030 and 2050 were associated with significant reductions in energy demand and based on improved efficiencies of combined heat and power (CHP) plants, increased electricity production from wind energy, replacement of fossil fuels with biomass and the introduction of electric vehicles. Specification of the future energy scenarios were done based on available strategies and political targets published by the Danish authorities [2,23]. A detailed overview of the technical measures adopted is presented in Table 1 . Table 2 provides detailed data for energy supply and demand for all energy scenarios while Table 3 provides data for the distribution of the energy consumption among the different transportation means. Further information regarding the energy modeling can be found elsewhere [4,5,16].

\section{Scenario}

The "2030" scenario represented a "link" between 2008 and the 2050 scenarios: more than $50 \%$ of the energy was generated from renewable resources. The transition to electric passenger vehicles was assumed to be incomplete and therefore ethanol was required as fuel in the energy system. The gross primary energy supply was estimated to 679.4 PJ while the final net consumption by society was $548 \mathrm{PJ}$ (excluding transmission losses). The higher efficiency of the energy system was mainly due to technical measures assumed to be implemented for reduction of the energy demand and supply [4]: e.g. decommissioning of old inefficient power plants, construction of new more efficient power units (utilizing SOFC, i.e. Solid Oxide Fuel Cells), implementation of geothermal units, reduction of electricity consumption in households (by 50\% compared to 2008) and in industry/services (by about 43\% compared to 2008), improvement and expansion of district heating networks for covering up to $70 \%$ of the heat demand, improved insulation of (old and new) buildings and decrease of fuel consumption in industry (about 31\% decrease compared to 2008). With respect to the transport sector, the expected growth in demand (18\%) was assumed covered equally by train transport (assuming expansion of railroads and of high speed trains) and by avoiding transport through introduction of road pricing and improved urban planning. In 2030 half of the passenger vehicles were assumed electric (or hybrid); the domestic flights were reduced to 5\% of the current level by substituting their capacity with high speed trains, and the fuel demand for ships was 
decreased by $40 \%$ compared to 2008 . The implementation of such measures in the energy analyses resulted in the energy scenario "2030" shown in Fig. 2. Industry required about $115 \mathrm{PJ}$ of 'gases' (as syngas and natural gas) and $13 \mathrm{PJ}$ of electricity to operate and produce heat required for the different industrial processes. Based on the gasification efficiencies (see Supporting Information, i.e. SI) to produce 85 PJ of syngas corresponding 117 PJ of biomass were needed. This was covered by available residual biomass resource (Supporting Information) and additional 40 PJ of energy crops (willow). Willow was selected as a favorable energy crop among other options (e.g. Miscanthus, poplar etc.) because of the high yield, low requirement of fertilizers and other agricultural practices, capacity of sequestering carbon, adaptability to different soils etc. [24,25]. However, the choice of Miscanthus or other short rotation coppice (SRC) would not significantly affect the results, as yield and fertilizers needs for these crops are similar [25]. The electricity needed for transport, industry (and services), household and individual heat pumps, adding up to about 123 PJ (including transmission losses) was produced from wind (84 PJ), hydropower/photovoltaic (8.3 PJ), CHP plants using syngas and a large share of methane (from anaerobic digestion of manure and grass) in SOFC (about 22.5 PJ), from combustion of oil, coal, waste and byproducts from biomass conversion (about 4 PJ) and industry (4.6 PJ). For heating, 180 PJ of heat were required; these were produced from solar heating (19 PJ), heat pumps (57 PJ), CHP plants using syngas, methane in SOFC (15 PJ), district heating plants burning coal, waste, byproducts from biomass conversion (79 PJ) and industry (9.5 PJ). In Fig. 2, the electricity needed for industrial heat pumps was taken into account as decreased electricity delivered to the net from the 'power units'. For transportation (details in Table 3), 0.8 PJ of methane, 72 PJ of diesel, 4.5 PJ of RME-biodiesel, 27.5 PJ of petrol, 4.7 PJ of bioethanol and 37.9 PJ of aviation fuel were required. Lastly, $33 \mathrm{PJ}$ of fossil fuels were needed to operate offshore platforms for extraction of oil and natural gas.

Table 3

2050 Scenarios 
For 2050, three different versions of the energy scenario were assessed. The three versions represented three fundamentally different approaches for production of transport fuels (all other aspects of these three alternatives (industry, power plants, household) were identical, see Fig. 3). In order to fulfill the energy demand, about 51 PJ of willow were required to be cultivated in addition to the estimated potential biomass resources. Most of the transportation was based on electricity produced from renewables (also identical in the three scenarios), except for heavy vehicles and aviation which required diesel and long-chain hydrocarbons (kerosene and aviation fuel). The final net energy consumption by society was 535 PJ (excluding transmission losses). Technical measures, similar to those in 2030, for reduction of the overall energy demand and supply were included (Table 1). These included: increase of renewables from wind, hydro and solar; further reduction of fuel consumption (33\% compared to 2008) in industry; 'avoided' passenger growth compared to 2030 (by implementing the same measures as in 2030); electrification of terrestrial transportation (now relying 100\% on electric vehicles) and improved efficiency of the ships (fuel demand lowered by $60 \%$ compared to 2008). These measures resulted in the energy flows shown in Fig. 3. The electricity needed for transport, industry (and services), households and individual heat pumps, adding up to about 180 PJ (including transmission losses) was produced from wind (133 PJ), hydropower/photovoltaic (25 PJ), CHP plants using syngas and a large share of methane (from anaerobic digestion of manure and grass) in SOFC (about $10 \mathrm{PJ}$ ), combustion of waste and byproducts from biomass conversion (about 10 PJ) and industry (3.6 PJ). About 178.6 PJ of heat were required for households and industry/services heating. These were produced from solar heating (19 PJ), heat pumps (57 PJ), CHP plants using syngas, methane in SOFC, district heating plants burning waste and byproducts from biomass conversion (overall $93 \mathrm{PJ}$ ) and industry (9.3 PJ). Compared to 2030, the fuel (as gas) needed to industry was reduced to 85 PJ. The remaining 'process heat' demand was covered with heat pumps (determining an electricity input from renewable intermittent sources, e.g. wind, of about 34 PJ). Instead, the production of the biodiesel for heavy terrestrial transport (e.g. lorries), ships and defence varied depending on the scenario. In "2050CSV" (i.e. 2050 conservative scenario), 63 PJ of crude oil was assumed to fulfill the demand for biodiesel (about 35 PJ) and aviation fuel (about 33 PJ). The gross primary 
energy supply was 559 PJ. In “2050RME” (i.e. 2050 scenario where biodiesel (as RME) is entirely produced from rapeseed), $35 \mathrm{PJ}$ rape methyl ester (RME) was assumed to fulfill the fuel demand of biodiesel supplemented by 33 PJ of crude oil for aviation. The gross primary energy demand was 576 PJ. In "2050BtL” (2050 scenario where biodiesel is produced from lignocellulosic biomass through BtL- and FT-technology, except for the share of RME corresponding to the amount already produced today in DK), $30.5 \mathrm{PJ}$ of FT-biodiesel from willow and 4.5 PJ of RME was assumed for terrestrial transportation, ships and defence supplemented by 33 PJ of crude oil for aviation. The gross energy demand was 588 PJ. It has to be noted that in Figs. 2-3, industry and electrolysis units are part of the energy system (they utilize electricity to produce other energy carriers). This should be realized when comparing data in Table 1-2 with Figs 2-3.

Figure 1

Figure 2

Figure 3

\subsection{Life-cycle inventory data}

\section{Biomass resources}

The relevant biomass resources available in Denmark were: manure, grass, lignocellulosic biomass (e.g. wood and straw) and waste. The total amount of biomass potential was estimated to be about 182.3 PJ. Focus was on residual biomass, i.e. waste (e.g. municipal solid waste, MSW) and byproduct/residues from agriculture and forestry (e.g. straw, manure, wood). Today most biomass resources have a function in the ecosystem or in the economy meaning that the utilization of these resources for energy production would induce changes in the ecosystem or in the society if status quo is to be maintained. As a consequence, the use of biomass resources for energy purposes instead of the current use (e.g. feeding, bedding, ploughing back to fields etc.) will finally lead to a competition between energy and other uses. The consequences of routing biomass resources to energy production were addressed in the LCA. Municipal solid waste quantities currently incinerated (40 PJ) were estimated to increase to 47 PJ in 2030 and 
2050 (no increases were assumed between 2030 and 2050 because additional recycling was anticipated). A detailed description of the biomass potential for Denmark is reported in the Supporting Information (SI).

\section{Energy conversion technologies}

Selection of the BtE conversion technologies was based on a number of considerations which implied energy system as well as technical issues for handling the biomass (see SI). The production of an intermediate energy carrier (e.g. biogas and syngas) was preferred to direct combustion for the flexibity and storability of the energy products which are needed to accommodate the fluctuations of energy systems with high penetration of wind power [26]. Manure and grass were assumed to be fermented to biogas through anaerobic digestion processes. Lignocellulosic biomass (e.g. wood, straw and willow) was assumed to be gasified for syngas generation. Biogas and syngas were then converted to heat and electricity in Solid Oxide Fuel Cells (SOFC) with high electricity efficiency (electricity efficiency 54\% and heat efficiency 36\%). In 2008 and 2050, MSW was assumed to be incinerated for heat and electricity production. In the 2030 scenario a share of the MSW (plastic) was however gasified to cover gas demands in industry. Biodiesel was produced from rapeseed and willow by means of transesterification and thermal process (gasification and Fischer-Tropsch), respectively.

Table 4 provides an overview of the background life-cycle inventory (LCI) data for (selected) Biomass-to-Energy (and to-fuel) processes used in the assessment. With respect to the LCIs for: wind, hydro and wave power, heat pumps, SOFC, fossil fuel combustion in combined heat and power (CHP) plants, district heating plants, peak-load boilers, vehicles, offshore platforms and industrial furnaces for heat production, common processes found in the Ecoinvent database [27] were used. A detailed description of the energy conversion technologies is reported in the SI.

Table 4

Land use changes 
Cultivation of energy crops requires use of land thereby inducing direct and indirect land use changes (dLUC and iLUC) under the basic assumption that land available for cultivation is constrained.

With respect to willow, the dLUC were estimated based on [28]. The iLUC were estimated based on the assumption that expansion of willow cultivated land in Denmark replaced the marginal crop (spring barley) which had to be produced somewhere else if status quo was to be maintained. The most likely consequence was assumed to be conversion of grassland into barley (69\%) as well as intensification of barley cultivation in Canada (31\%) [29,30]. The land use consequence of replacing prairie grass with barley was $84 \mathrm{Mg} \mathrm{CO} /$ ha. Intensification implied a larger utilization of fertilizers in order to increase the production on the same constrained land $(1 \mathrm{~kg} \mathrm{~N} / \mathrm{ha}$ for Canadian conditions).

With respect to rapeseed, dLUC and iLUC were quantified according to [30] assuming conversion of set-aside land into rapeseed (all 2050 scenarios) or conversion of set-aside land and arable land (spring barley) into rapeseed (only the "2050RME" scenario). For conversion of arable land (spring barley) into rapeseed, a carbon loss of $0.115 \mathrm{Mg} \mathrm{C} / \mathrm{ha} / \mathrm{y}$ was assumed according to [28]. Only dLUC and iLUC associated with changes in rapeseed cultivation from the current situation to the future needs were considered.

The uncertainties in the assumptions were addressed in the sensitivity analysis. Table 5 provides an overview of the background data used to evaluate the dLUC. A detailed discussion of the impacts associated with land use changes is reported in the Supporting Information.

\section{Table 5}

\section{Management of agricultural and biomass conversion residuals}

The removal of straw from fields induces changes in the soil carbon stock. The calculated carbon depletion was $0.09 \mathrm{Mg} \mathrm{C} / \mathrm{Mg}$ straw [31]. Removal of nutrients (N, P and K) with the straw led to additional fertilizer use to maintain constant crops yields. Straw removal 
also induced to decrease $\mathrm{N}_{2} \mathrm{O}$ emissions: a decrease of $0.03 \mathrm{~kg} \mathrm{~N}-\mathrm{N}_{2} \mathrm{O} / \mathrm{Mg}$ DM straw was assumed based on [31].

The use of grass for energy instead of feeding induced an increased demand for other types of fodder. This was modeled with additional production of barley in order to satisfy the feed demand.

The use on land of digestate from anaerobic digestion of manure was credited by substitution of inorganic N, P, K fertilizers [32,33]. Application of $1 \mathrm{Mg}$ of digestate was assumed to substitute $4.07 \mathrm{~kg}$ of ammonium nitrate (as $\mathrm{N}$ ), $2.1 \mathrm{~kg}$ of triple superphosphate (as $\mathrm{P}_{2} \mathrm{O}_{5}$ ) and $3.3 \mathrm{~kg}$ of potassium chloride (as $\mathrm{K}_{2} \mathrm{O}$ ). The higher amount of $\mathrm{N}$ substituted (compared to direct application on land of raw manure) was a consequence of the higher availability of $\mathrm{N}$ in the digestate after the selected manure treatment. This has been thoroughly discussed in [32,33].

The use on land of biochar was also credited for its potential positive effects on soil, e.g. carbon sequestration, improved fertilizer efficiency and reduced $\mathrm{N}_{2} \mathrm{O}$ emissions, based on [34]. A detailed description of the assumptions regarding management of agricultural and biomass conversion residuals is reported in the Supporting Information.

\section{Results and discussion}

The results are presented with respect to the environmental impact categories: global warming (GW), acidification (AC), aquatic eutrophication (EP) and land occupation (LO) in Fig. 4. For eutrophication, distinction was made between impacts caused by nitrogen emissions (EP (N)) and eutrophication caused by phosphorous emissions (EP (P)). For the purpose of clarity, only results for EP (N) are included in Fig. 4. The results for aquatic eutrophication related to phosphorous (EP (P)) were similar to those of nitrogen, EP (N), and are presented only in Table 6.

The results for the category land occupation are presented as additional land required $\left(10^{4} \Delta \mathrm{m}^{2} / \mathrm{PJ}\right.$ PES $)$ compared with the current situation (“2008”). For acidification, the results are expressed as area of unprotected ecosystem that exceeds the critical load of

acidification as a consequence of the emissions (i.e. $10^{4} \mathrm{~m}^{2} / \mathrm{PJ}_{\mathrm{PES}}$ ). The impacts were calculated per unit of primary energy supply provided to the energy system (i.e. $\mathrm{PJ}_{\mathrm{PES}}$ ) 
(e.g. $\mathrm{Gg} \mathrm{CO}_{2}$-eq/PJ $/ \mathrm{PES}_{\mathrm{PS}}$ ). This provided the intensity of the environmental impact and allowed comparison of scenarios with different primary energy supply.

To enable a more direct comparison between the individual energy scenarios, Table 6 provides both normalized and total environmental impacts for the energy scenarios. Additionally, "total" values ("Total REF") were calculated for each energy scenario under the assumption that the primary energy supply was identical to the reference year 2008 (864 PJ). The intention with these values was to illustrate the effects from decreasing energy demand vs. the effects from changing the energy supply. Only the sub-processes (e.g. transportation, LUC, fossil fuel combustion, etc.) contributing to the overall impacts with more than $1 \%$ are shown.

Fig. 5 shows the environmental impacts associated with the production and combustion of the transport fuels RME and FT-biodiesel compared with traditional diesel. In this case the results presented in Fig. 4 were re-calculated in order to correspond to a functional unit of 1 energy unit of diesel-fuel. The intention with this calculation was to clarify the environmental impacts related to the individual fuels for better comparison.

Figure 4

\subsection{Global warming (GW)}

Overall, the results for GW indicated decreasing intensity of the GHGs emissions per unit of primary energy supply from 2008 (about $68 \mathrm{Gg} \mathrm{CO}$-eq/PJ $\mathrm{PES}_{\text {) }}$ to 2050 (about 17-31 $\mathrm{Gg} \mathrm{CO}$-eq/ $\mathrm{PJ}_{\mathrm{PES}}$ depending on the scenario). The reduction of GHGs emissions (per $\mathrm{PJ}_{\mathrm{PES}}$ ) was thus in the range of $66 \%-80 \%$. This was primarily attributed to the substitution of fossil fuel with biomass resources, the increased wind energy penetration in the system and to the conversion of transport to electric passenger vehicles. Only partial conversion of transport to electric vehicles in "2030" (still relying on fossil fuel for $50 \%$ of passenger vehicles) explained the higher impacts compared to 2050s where electrification of passenger vehicles was completed. The total GHGs emissions decreased from $58 \mathrm{Tg}$ in "2008” to $26 \mathrm{Tg}$ in "2030" and 10-18 Tg in the 2050s (depending on the scenario). It has

to be noted that the total GHGs emissions calculated for 2008 (58 Tg) is higher than the 
value (48.4 Tg) indicated in the Countries official statistics by [35] as this latter one only counted for emissions associated with the fuels combustion (i.e. upstream emissions associated with fuel production and provision were not included).

The decrease on the total GHGs emissions was both attributed to the decreased impact intensity (impact per $\mathrm{PJ}_{\mathrm{PES}}$ ) and to the diminished energy demand. As shown in Table 6, if the total energy supply was the same as "2008" (864 PJ), the total impact for GW would still be significantly lower than today. Although the energy mix (i.e. share of electricity, heat and fuel) differed in the selected periods compared to "2008", Table 6 demonstrates that the benefits were primarily attributed to the substitution of fossil fuels with biomasses, the increased wind penetration and the conversion to electric passenger vehicles, rather than to the diminished energy demand (and consequent supply).

The preferred scenarios from a GW perspective were the "2050BtL" and "2050CSV" scenarios whereas the worst was the "2050RME" scenario. The difference among the 2050 scenarios was caused by the magnitude of iLUC impacts associated with energy crops cultivation for biodiesel production to cover the demand for heavy terrestrial transportation, ships and defense. The impacts associated with LUC (i.e. sum of dLUC and iLUC) were estimated to 5, 18 and $8 \mathrm{Gg} \mathrm{CO}_{2}$-eq/PJPES in the "2050CSV", "2050RME" and "2050BtL" scenarios, respectively. The impacts associated with rapeseed cultivation in "2050RME" were significantly higher than those for willow in "2050BtL" due to the lower yield of rapeseed and hence higher iLUC. In this context, the use of (traditional fossil) diesel for heavy transport, ships and defense was still favorable over RME, whereas FT-biodiesel production (the "2050BtL” scenario) showed slightly lower GW impacts than fossil diesel. Although the results for FT-biodiesel strongly depended on the assumptions regarding biochar effects and willow yield, this demonstrated that the considerable iLUC's associated with cultivation of energy crops can completely off-set the benefits of biofuels (see further discussion of biofuels in section 3.3). Lastly, it should be noted that use on land of digestate and biochar led to significant GW savings due to the return of nutrients and carbon to the soil.

\subsection{Acidification (AC), aquatic eutrophication (EP) and land occupation (LO)}


The results for AC followed the trends observed for GW. Decreased $\mathrm{NO}_{\mathrm{x}}$ and $\mathrm{SO}_{\mathrm{x}}$ emissions from fossil fuel combustion in power plants lowered the intensity of the acidification impact compared to "2008". The best scenario was "2050CSV" contributing with a load of $12210^{4} \mathrm{~m}^{2} / \mathrm{PJ} \mathrm{JES}_{\mathrm{PE}}$, while the "2050BtL" scenario at $13510^{4} \mathrm{~m}^{2} / \mathrm{PJ} \mathrm{PES}_{\text {PEs }}$ second best. In the "2050BtL"scenario, the environmental load was mainly associated with tailpipe emissions of $\mathrm{NO}_{\mathrm{x}}$ from biodiesel combustion in heavy vehicles and ships (corresponding to about $5810^{4} \mathrm{~m}^{2} / \mathrm{PJ}_{\mathrm{PES}}$ ). Biodiesel-fuelled heavy vehicles generally have higher $\mathrm{NO}_{\mathrm{x}}$ emissions than conventional diesel-fuelled vehicles [36-39]. A similar situation was also the case for "2050RME" where biodiesel for heavy transport and ships was produced from rapeseed. Among the 2050 scenarios, the worst environmental performance for AC was observed for "2050RME" (178 $10^{4} \mathrm{~m}^{2} / \mathrm{PJ}_{\mathrm{PES}}$ ) where cultivation of rapeseed contributed with $3410^{4} \mathrm{~m}^{2} / \mathrm{PJ} \mathrm{PES}$ (N-fertilizers) in addition to the tailpipe $\mathrm{NO}_{\mathrm{x}}$ related impacts. The scenario "2030" had higher impacts than 2050s due to higher consumption of fossil fuels in the power and transport sectors. In the 2050 scenarios, fossil fuels were largely replaced with wind power. For all the selected scenarios, the total acidification impacts were significantly lower than today's due to both the decreased impact intensity and to the reduced primary energy supply (the latter one as a consequence of the reduced demand) (Table 6).

For aquatic eutrophication ( $\mathrm{N}$ and $\mathrm{P}$ ), all the assessed scenarios contributed with significant impacts, mainly associated with the increased use of fertilizers for energy crop production and the increased use on land of digestate from anaerobic digestion of grass and manure, with consequent potential release of nitrates and phosphates to surface waters. For both eutrophication categories, the least preferable scenario was "2050RME" (29 $\mathrm{Mg} \mathrm{N} / \mathrm{PJ}_{\mathrm{PES}}$ and $3.9 \mathrm{Mg} \mathrm{P} / \mathrm{PJ}_{\mathrm{PES}}$ ): the potential eutrophication impact related to nitrogen was doubled whereas the impact associated with phosphorous increased by one order of magnitude compared with "2008". This was due to the large amounts of fertilizers required for rapeseed and barley cultivation as a consequence of the cascading effects associated with replacement of the marginal crop in Denmark (spring barley). A significant increased in phosphorous emissions was observed as a consequence of i) application on land of digestate (all 2030 and 2050 scenarios) and ii) energy crops cultivation with related cascading effects (primarily for "2050RME” due to rapeseed 
cultivation); this increase represents a potential problem for inland water ecosystems where $\mathrm{P}$ is typically the limiting nutrient for algae and plants growth.

Cultivation of willow in "2050BtL" required significantly less fertilizers than cultivation of rapeseed in the "2050RME" scenario, thereby causing lower impacts related to aquatic eutrophication. This was in agreement with several other studies, e.g. [40]. The EP impacts associated specifically with transportation was highest in the 2050 scenarios including biodiesel-fuelled heavy vehicles (“2050RME” and "2050BtL”) because of higher $\mathrm{NO}_{\mathrm{x}}$ tailpipe emissions, also in accordance with the results for AC.

The "2050RME" and "2050BtL" scenarios required the largest area of land (additional 2089 and $178710^{4} \mathrm{~m}^{2} / \mathrm{PJ}_{\mathrm{PES}}$, respectively, compared with “2008”). This was caused by cascading effects due to the cultivation of energy crops in Denmark and subsequent displacement-replacement mechanisms as previously mentioned. The scenarios “2030” and "2050CSV” required significantly less additional land due to use of fossil fuels for heavy terrestrial transportation, ships and defense in place of biodiesel.

\section{Table 6}

\subsection{Impacts for biodiesel production}

Among the three evaluated scenarios for diesel-like fuel production (needed for heavy terrestrial transport, ships and defense), RME was by far the least desirable option with respect to all environmental impact categories. With respect to $\mathrm{GW}$, the impact was estimated to $287 \mathrm{Gg} \mathrm{CO}_{2}-\mathrm{eq} / \mathrm{PJ}$ of fuel, whereas for fossil diesel the corresponding value was about $89 \mathrm{Gg} \mathrm{CO}_{2}$-eq/PJ of fuel. These results clearly illustrate the importance of the large upstream GW impacts related to land use changes (LUC) and are in agreement with other findings in literature (e.g. [41,42]).

The impacts from FT-biodiesel were in the range of 65-88 $\mathrm{Gg} \mathrm{CO}_{2}$-eq/PJ of fuel depending on assumptions regarding benefits from biochar (see sensitivity analysis). RME-biodiesel was also the least favorable option in relation to the AC, EP and LO categories. With respect to AC and EP (N and P), the loads were mainly associated with tailpipe emission of $\mathrm{NO}_{\mathrm{x}}$ and use of $\mathrm{N}$ and $\mathrm{P}$ fertilizers for crop cultivation, as previously explained. This was also the case for FT-biodiesel. However, the impacts for AC and EP 
( $\mathrm{N}$ and P) associated with cultivation of willow for FT-biodiesel production was significantly lower than RME due to the higher yield and reduced fertilizer use.

Fig. 5 shows the potential environmental impacts associated with diesel and biodiesel production. The impacts for the category EP (P) (not shown in Fig. 5) equaled 0.1, 28 and $8 \mathrm{Mg}$ P/PJ respectively for diesel, RME and FT-biodiesel.

Figure 5

\subsection{Sensitivity analysis}

The sensitivity of the results towards changes in assumptions and parameters was carried out in order to assess the significance of: 1) willow yield, 2) magnitude of iLUC associated with cultivation of rapeseed, 3) efficiency of the BtL processes and 4) biochar effects on GW. Acknowledging the level of uncertainty associated with parameter selection, these aspects were identified by random parameter variation as having the largest potential for affecting the overall conclusions. 1) The yield of willow (baseline value: $11.8 \mathrm{Mg} \mathrm{DM} / \mathrm{ha}$ ) was varied between 7 and $16 \mathrm{Mg} \mathrm{DM} / \mathrm{ha}$ which is a likely range for Denmark [43]. 2) The iLUC associated with rapeseed (baseline values in Table 5) was estimated according to [41] thereby decreasing the impacts compared with the baseline scenarios. An average value of $1.32 \mathrm{~kg} \mathrm{CO} / \mathrm{kg}$ rapeseed was assumed (only effects related to GW was assessed as no data for impacts in other impact categories were available). 3) The efficiency of the BtL process (baseline value: $40 \%$ ) was set to $57 \%$ with use of hydrogen generated from wind power electrolysis of water (excess wind power was assumed to be available). 4) No benefits for GW from biochar were assumed (for the baseline assumptions see SI). Results from the sensitivity analysis are presented in Table 7.

Assuming a lower yield for willow (1) made the use of fossil fuel for heavy transport favorable to FT-biodiesel produced from lignocellulosic biomass, according to all impact categories. Conversely, increased yield would be beneficial for all impact categories, especially with respect to the "2050BtL" scenario where willow is used as substrate for FT-biodiesel production. A new value for iLUC (2) changed the overall result for GW for the "2050RME" scenario. The impacts associated with iLUC 
significantly decreased ( $\Delta=-11 \mathrm{Gg} \mathrm{CO} \mathrm{CO}_{2}-\mathrm{eq} / \mathrm{PJ}_{\mathrm{PES}}$ ) compared with the baseline scenario. This difference however did not affect the overall ranking of the 2050 scenarios: the scenario based on RME was still the least favorable.

More efficient thermochemical processes (3) combined with electricity supply from wind power only slightly improved the environmental performance of biofuel production via thermochemical conversion. Although several technologies for utilization

of excess wind power in future energy systems will exist, it should be noted that constraints (e.g. capacity and interconnectors) in the electricity system may be limiting utilization of this electricity and that local storage/utilization technologies may be needed. Regarding biochar (4), the performance of the "2050BtL" scenario became similar to the "2050CSV" scenario if carbon sequestration from biochar was not included, i.e. FTbiodiesel did not contribute with savings in the GW category compared with fossil diesel.

Overall, the sensitivity analysis revealed that the quantification approach for LUC impacts, the assumption regarding yields of energy crops and potential benefits from biochar use can significantly affect the overall result of the LCA. However, despite these effects, the overall ranking of the individual energy scenarios did not change. The overall results based on the assessed scenarios are therefore considered robust and not sensitive towards changes in assumptions.

\section{Table 7}

\section{Conclusion}

The environmental impacts related to four potentially future energy scenarios for Denmark were compared with the energy system in 2008 by means of LCA. It was demonstrated that: 1) significant reductions in GHGs emissions and global warming impacts can be achieved per PJ of energy supplied, 2) residual domestic biomass resources were insufficient to cover demand for biomass energy thereby requiring cultivation of energy crops which caused significant environmental loads in most impact categories, 3) large impacts associated with upstream land use changes (LUC) made the use of fossil diesel for heavy transport favorable to RME- and FT-biodiesel, and 4) high potential aquatic eutrophication effects were a direct consequence of energy crops 
cultivation. Reduction of the energy demand, increased share of wind power, and replacement of fossil fuels with residual domestically available biomasses represented the main means for GHGs emissions savings in the future energy scenarios. However, by far the main "environmental challenge" was the supply of biofuels for heavy terrestrial transport, ships, defense and aviation. Use of energy crops to fulfill this demand caused significant environmental impacts related to global warming (mainly due to LUC), aquatic eutrophication (increased fertilizers use) and land occupation. Consequently, use of fossil diesel for these applications appeared preferable over the biomass based fuels, except for global warming where FT-biodiesel performed slightly better. The recommendation, therefore, is to focus on residual domestically available biomasses and minimize energy crops production.

\section{Acknowledgments}

The authors acknowledge the inputs and contributions from Brian Vad Mathiesen (Aalborg University), Niclas Bentsen (Copenhagen University) and Lorie Hamelin (Southern Denmark University). Financial support for this study was provided by a research grant ("CEESA" 2104-06-0007) from the Danish Research Council as well as from the Technical University of Denmark. The authors wish to thank two anonymous reviewers for detailed and valuable comments.

\section{Supporting Information (SI)}

Additional information on inventory data for: biomass resources, energy conversion technologies, land use changes and management of agricultural and biomass conversion residuals can be found in the Supporting Information (SI).

\section{References}

[1] Danish Energy Agency (DEA), Energistatistik 2009, Copenhagen (Denmark): Energistyrelsen (Danish Energy Agency) (2010).

[2] Danish Ministry of Climate, Energy and Buildings, Our future energy. Copenhagen (Denmark): Danish Ministry of Climate, Energy and Buildings (2011).

[3] Y.P. Li, G.H. Huang, X. Chen, Planning regional energy system in association with greenhouse gas mitigation under uncertainty, Appl. Energy 88 (2011) 599-611. 
[4] B.V. Mathiesen, H. Lund, K. Karlsson, 100\% Renewable energy systems, climate mitigation and economic growth, Appl. Energy 88 (2011) 488-501.

[5] B.V. Mathiesen, H. Lund, K. Karlsson, IDAs Klimaplan 2050, baggrundsrapport Tekniske systemanalyser, brændselsforbrug, drivhusgasser, samfund søkonomiske konsekvenser, erhvervspotentialer, beskæftigelseseffekter samt helbredsomkostninger (IDAs Climate Plan 2050, background report in Danish and English), Copenhagen (Denmark): Danish Society of Engineers (IDA, Ingeniørforeningen Danmark) (2009).

[6] B.V. Mathiesen, H. Lund, F.K. Hvelplund, D. Connolly, N.S. Bentsen, D. Tonini, P.E. Morthorst, H. Wenzel, T. Astrup, N.I. Meyer, M. Münster, P.A. Østergaard, B. BakJensen, M.P. Nielsen, E. Schaltz, J.R. Pillai, L. Hamelin, C. Felby, K. Heussen, P. Karnøe, J. Munksgaard, L. Pade, F.M. Andersen, K. Hansen, CEESA 100\% Renewable Energy Scenarios towards 2050. Aalborg (Denmark): Aalborg University. Available from: http://www. ceesa. plan. aau. dk (accessed December 2011) (2011).

[7] A. Franco, P. Salza, Strategies for optimal penetration of intermittent renewables in complex energy systems based on techno-operational objectives, Renewable Energy 36 (2011) 743-753.

[8] D. Connolly, H. Lund, B.V. Mathiesen, M. Leahy, The first step towards a $100 \%$ renewable energy-system for Ireland, Appl. Energy 88 (2011) 502-507.

[9] C. Cosmi, S. Di Leo, S. Loperte, M. Macchiato, F. Pietrapertosa, M. Salvia, V. Cuomo, A model for representing the Italian energy system: The NEEDS-TIMES experience, Renewable \& sustainable energy reviews 13 (2009) 763-776.

[10] D.J. Treffers, A.P.C. Faaij, J. Spakman, A. Seebregts, Exploring the possibilities for setting up sustainable energy systems for the long term: two visions for the Dutch energy system in 2050, Energy Policy 33 (2005) 1723-1743.

[11] M.A. Rubio Rodriguez, J.D. Ruyck, P.R. Diaz, V.K. Verma, S. Bram, An LCA based indicator for evaluation of alternative energy routes, Appl. Energy 88 (2011) 630635.

[12] R.R. Tan, K.B. Aviso, I.U. Barilea, A.B. Culaba, J.B. Cruz Jr., A fuzzy multiregional input-output optimization model for biomass production and trade under resource and footprint constraints, Appl. Energy 90 (2012) 154-160.

[13] B.V. Mathiesen, H. Lund, P. Noergaard, Integrated transport and renewable energy systems, Utilities Policy 16 (2008) 107-116.

[14] H. Lund, W. Kempton, Integration of renewable energy into the transport and electricity sectors through V2G, Energy Policy 36 (2008) 3578-3587.

[15] H. Wenzel, M.Z. Hauschild, L. Alting, Environmental Assessment of Products, Volume 1, (1997). 
[16] H. Lund, B.V. Mathiesen, Energy system analysis of 100\% renewable energy systems: The case of Denmark in years 2030 and 2050, Energy 34 (2009) 524-531.

[17] M. Hauschild, J. Potting, Spatial differentiation in Life Cycle impact assessment The EDIP2003 methodology, Environmental News No. 80. Copenhagen (Denmark): Danish Ministry of the Environment (2005).

[18] O. Jolliet, M. Margni, R. Charles, S. Humbert, J. Payet, G. Rebitzer, R. Rosenbaum, IMPACT 2002+: A new life cycle impact assessment methodology, Int J Life Cycle Assess 8 (2003) 324-330.

[19] G.A. Finnveden, M.Z. Hauschild, T. Ekvall, J. Guinee J.B., R. Heijungs, S. Hellweg, A. Koehler, D. Pennington, S. Suh, Recent developments in Life Cycle Assessment, J. Environ. Manage. 91 (2009) 1-21.

[20] Pre' Consultants, Simapro 7.1, www. pre.nl. (accessed January 2009) (2009).

[21] O. Cencic, H. Rechberger, Material Flow Analysis with Software STAN, Journal of environmental management 18(1) (2008) 3-7.

[22] Danish Energy Agency (DEA), Energistatistik 2008. Copenhagen (Denmark): Energistyrelsen (Danish Energy Agency) (2009).

[23] Klimatkommisionen (Danish Commission on Climate Change Policy), Green energy - the road to a Danish energy system without fossil fuels. Copenhagen (Denmark): Danish Commission on Climate Change Policy (2010).

[24] I. Callesen, P.E. Grohnheit, H. Oesterga, Optimization of bioenergy yield from cultivated land in Denmark, Biomass \& bioenergy 34 (2010) 1348-1362.

[25] C. Boehmel, I. Lewandowski, W. Claupein, Comparing annual and perennial energy cropping systems with different management intensities, Agricultural Systems 96 (2008) 224-236.

[26] H. Lund, Renewable energy strategies for sustainable development, Energy 32 (2007) 912-919.

[27] N. Jungbluth, M. Chudacoff, A. Dauriat, F. Dinkel, G. Doka, E.M. Faist, E. Gnansounou, N. Kljun, K. Schleiss, M. Spielmann, C. Stettler, J. Sutter, Life Cycle Inventories of Bioenergy. Uster (Switzerland): Swiss Centre for Life Cycle Inventories, ESU-services, Ecoinvent report No 17 (2007).

[28] S.S. Clair, J. Hillier, P. Smith, Estimating the pre-harvest greenhouse gas costs of energy crop production, Biomass \& bioenergy 32 (2008) 442-452.

[29] J.H. Schmidt, System delimitation in agricultural consequential LCA - Outline of methodology and illustrative case study of wheat in Denmark, The international journal of life cycle assessment 13 (2008) 350-364. 
[30] J.H. Schmidt, Life cycle assessment of rapeseed oil and palm oil, $\mathrm{PhD}$ thesis. Aalborg (Denmark): Aalborg University (2007).

[31] F. Cherubini, S. Ulgiati, Crop residues as raw materials for biorefinery systems - A LCA case study, Appl. Energy 87 (2010) 47-57.

[32] L. Hamelin, M. Wesnaes, H. Wenzel, B.M. Petersen, Environmental Consequences of Future Biogas Technologies Based on Separated Slurry, Environ. Sci. Technol. 45 (2011) 5869-5877.

[33] L. Hamelin, M. Wesnæs, H. Wenzel, B.M. Petersen, Life cycle assessment of biogas from separated slurry, Environmental project 1329. Copenhagen (Denmark): Danish Environmental Protection Agency. http://www.mst.dk/Publikationer/Publications/2010/07/978-87-92668-035.htm (accessed January 2011) (2010).

[34] K.G. Roberts, B.A. Gloy, S. Joseph, N.R. Scott, J. Lehmann, Life Cycle Assessment of Biochar Systems: Estimating the Energetic, Economic, and Climate Change Potential, Environ. Sci. Technol. 44 (2010) 827-833.

[35] International Energy Agency (IEA), $\mathrm{CO}_{2}$ emissions from fuel combustion highlights. Paris (France): International Energy Agency (IEA) (2011).

[36] L. Zhu, W. Zhang, W. Liu, Z. Huang, Experimental study on particulate and NOx emissions of a diesel engine fueled with ultra low sulfur diesel, RME-diesel blends and PME-diesel blends, Sci. Total Environ. 408 (2010) 1050-1058.

[37] J. Sun, J.A. Caton, T.J. Jacobs, Oxides of nitrogen emissions from biodiesel-fuelled diesel engines, Progress in Energy and Combustion Science 36 (2010) 677-695.

[38] C. Mazzoleni, H.D. Kuhns, H. Moosmuller, J. Witt, N.J. Nussbaum, M.C.O. Chang, G. Parthasarathy, S.K.K. Nathagoundenpalayam, G. Nikolich, J.G. Watson, A case study of real-world tailpipe emissions for school buses using a $20 \%$ biodiesel blend, Sci. Total Environ. 385 (2007) 146-159.

[39] W.G. Wang, D.W. Lyons, N.N. Clark, M. Gautam, P.M. Norton, Emissions from nine heavy trucks fueled by diesel and biodiesel blend without engine modification, Environmental science \& technology 34 (2000) 933-939.

[40] L.P. Abrahamson, T.A. Volk, R.F. Kopp, E.H. White, J.L. Ballard (Ed.), Willow Biomass producer's Handbook. Syracuse (NY): Short-Rotation Woody Crops Program, SUNY-ESF (2002).

[41] J. Ros, K. Overmars, J. Notenboom, How to deal with indirect land-use change in the EU Renewable Energy Directive? (2010).

[42] H.J. Croezen, G.C. Bergsma, M.B.J. Otten, M.P.J. Van Valkengoed, Biofuels: indirect land use change and climate impact. Delft (The Netherlands): CE Delft (2010). 
[43] G. Kunikowski, E. Gańko, M. Pisarek, L.J. Nilsson, K. Ericsson, J. Witt, C. Panoutsou, A. Nikolaou, M.F. Emmenegger, K. McDonnell, D. Buttle, Review Regional energy crops experience. Warsaw (Poland): EC Baltic Renewable Energy Centre ECBREC/IBMER (2007).

[44] Danish Energy Agency (DEA), Fjernkøling i Danmark (District Cooling in Denmark). Copenhagen (Denmark): Energistyrelsen (Danish Energy Agency) (2007).

[45] H. Tommerup, S. Svendsen, Energy savings in Danish residential building stock, Energy and buildings 38 (2006) 618-626.

[46] K. Wittchen, Potentielle energibesparelser i det eksisterende byggeri Skærpedekrav til nybyggeriet 2010 og fremover-Økonomisk analyse (Increased demandsfor buildings standards from 2010). Hørsholm (Denmark): Statens Byggeforskningsinstitut (Danish Building Research Institute) (2009).

[47] S. Aggerholm, Skærpede krav til nybyggeriet 2010 og fremover-Økonomisk analyse (Increased demands for buildings standards from 2010). Hørsholm (Denmark): Statens Byggeforskningsinstitut (Danish Building Research Institute) (2009).

[48] M. Johansen, M. Hansen, J. Mikkelsen, Energibesparelser i erhvervslivet (Energy savings within industry and service). Copenhagen (Denmark): Dansk Energi Analyse A/S og Weel og Sandvig Aps (2009).

[49] H. Lund, B. Mathiesen, Ingeniørforeningens Energiplan 2030 - Tekniske energisystemanalyser, samfundsøkonomisk konsekvensvurdering og kvantificering af erhvervspotentialer. Baggrundsrapport (Danish Society of Engineers' Energy Plan 2030). Copenhagen (Denmark): Danish Society of Engineers (Ingeniørforeningen Danmark) (2006).

[50] O. Nielsen, A. Landex, J. Rørbech, Fremtidsscenarier for transport i Danmark (Future scenarios for transport in Denmark). Copenhagen (Denmark): Ugebladet Ingeniøren (2006).

[51] J. Ahrenfeldt, U. Henriksen, T.K. Jensen, B. Goebel, L. Wiese, A. Kather, H. Egsgaard, Validation of a continuous combined heat and power (CHP) operation of a two-stage biomass gasifier, Energy \& Fuels 20 (2006) 2672-2680.

[52] U. Arena, F.D. Gregorio, M. Santonastasi, A Techno-Economic Comparison Between Two Design Configurations for a Small Scale, Biomass-to-Energy Gasification Based System, Chem. Eng. Journal 162 (2010) 590.

[53] U. Arena, L. Zaccariello, M.L. Mastellone, Fluidized bed gasification of wastederived fuels, Waste Manage. 30 (2010) 1212-1219. 
[54] J.D. Bentzen, C. Hindsgaul, U.B. Henriksen, L.H. Soerensen, Straw Gasification in a Two-Stage Gasifier, Proceedings of the 12.European Biomass Conference (2002) 577580.

[55] T. Fruergaard, T. Astrup, T. Ekvall, Energy use and recovery in waste management and implications for accounting of greenhouse gases and global warming contributions, Waste Manage. Res. 27 (2009) 724-737.

[56] N. Jungbluth, R. Frischknecht, M.F. Emmenegger, R. Steiner, M. Tuchschmid, Life Cycle Assessment of BTL-fuel production: Inventory Analysis, RENEW, Renewable fuels for advanced powertrains; ESU-services Ltd Del-5.2.7-inventory-final.doc (2007).

[57] J. Larsen, M. Østergaard Petersen, L. Thirup, H. Wen Li, F. Krogh Iversen, The IBUS Process - Lignocellulosic Bioethanol Close to a Commercial Reality, Chem. Eng. Technol. 31 (2008) 765-772. 


\section{Tables}

Table 1 Overview of the technical measures adopted in the energy scenarios for 2030 and 2050 to decrease energy demand. A detailed energy system analysis of the scenarios can be found in $[4,5,16]$. The resulting energy balance with respect to heat, electricity and transport fuel production is shown in Figs. 2-3 and Table 2-3. SOFC: Solide Oxide Fuel Cell; CHP: Combined Heat and Power.

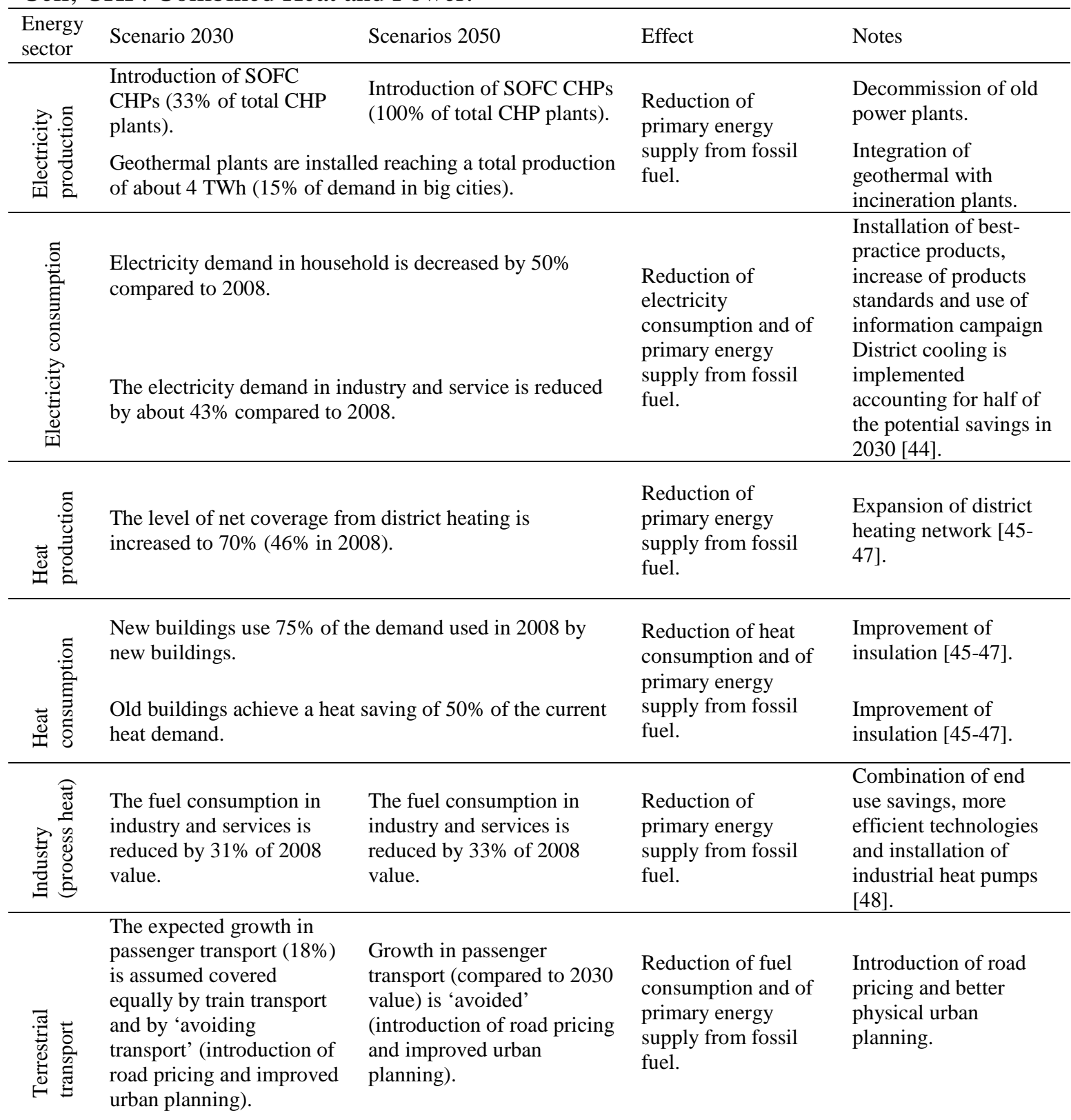


Vehicles meet $60 \%$ of the transport demand.

Railroads meet $30 \%$ of the transport demand.

Bicycling and walking

meet $10 \%$ of the transport

demand (5\% in 2008).

Bioethanol covers about

$5 \%$ of the passenger

transport.

Half of the good transport

is diverted to ships and

trains.
Vehicles meet $50 \%$ of the transport demand. Railroads meet $40 \%$ of the transport demand.

Bicycling and walking meet $10 \%$ of the transport demand (5\% in 2008) No bioethanol is needed for transportation

Reduction of primary energy supply from fossil fuel.

Reduction of fuel consumption and of primary energy supply from fossil fuel.

Reduction of fuel consumption and of primary energy supply from fossil fuel.
Expansion of railroads (higher capacity and higher speed) and implementation of better physical urban planning [49,50] Installation of loading stations; electric vehicles are also needed as storage system to accommodate electricity fluctuations.

Introduction of road pricing and expansion of railroads.

Expansion of railroads and improvement of fuel-combustion technology of the planes.

Improvement of fuelcombustion technology of the ships. 
Table 2 Energy supply and demand in the individual energy scenarios years (PJ; rounded values): 2050CSV (conservative, fossil diesel used for heavy terrestrial transport), 2050RME (RME-biodiesel used for heavy terrestrial transport), 2050BtL (FT-biodiesel mainly produced through BtL for heavy terrestrial transport). Primary energy represents the amount of energy supplied to the energy system with biomass, fossil fuels and renewables. 'Tot' refers to the final energy (sum of electricity, heat, fuel and 'nonenergy' use) delivered to consumers in society (three values are provided with and without including industry, electrolysis and transmission losses).

20082030

2050CSV
2050RME

2050BtL

\section{Energy supply:}

Fossil fuel*

$704 \quad 293$

87

40

40

Primary energy (total)

$864 \quad 679$

559

576

588

\section{Energy demand (electricity):}

Household

$37 \quad 18.4$

18.4

18.4

18.4

Individual heat pumps

$1.8 \quad 6.1$

5.8

5.8

5.8

Industry/services

8348

46

46

46

Industrial heat pumps

$-13.1$

34

34

Other $^{\dagger}$

- $\quad-$

$-3.2$

$-3.2$

$-3.2$

Transport sector

$1.4 \quad 24.1$

43.3

43.3

43.3

Electrolysis units

$\begin{array}{lll}-\quad & -\end{array}$

Tot (exc. industry, electrolysis, transm. loss) ${ }^{\ddagger}$

$40 \quad 97$

27

Tot (inc. industry, electrolysis; exc. transm. loss)

$123 \quad 110$

111

171

111

27

Tot (incl. industry, electrolysis and transm. loss)

$131 \quad 119$

180

171

\section{Energy demand (heat):}

Household 147

147

147

Industry (process heat)

114

106

106

Industry/services

33.5

31.6

31.6

31.6

Total

$298^{\beta} \quad 294$

284

284

284

Fuel for transport

$220 \quad 147$

80

80

'Non-energy' use

$11-$

Tot (exc. industry, electrolysis, transm. loss)

$609 \quad 538$

$-$

$652 \quad 548$

$660 \quad 557$

557

544

475

475

475

Tot (incl. industry, electrolysis and transm. loss)

* The share of fossil fuel in the waste (e.g. plastic) is excluded from the values provided.

$\dagger$ Sum of ethanol, biogas production, district cooling and electrical cartridges. In 2050 this was modeled as a negative consumption as it provided net electricity to the energy system $[4,5,16]$.

¥ Net electricity delivered to final consumers (transmission losses are included in the calculation). When comparing with the values in Figs. 1-3, it has to be kept in mind that in the Figs. the electricity (from renewables) consumed by industry and electrolysis units is visualized as internal flow as industry and electrolysis units are part of the energy system (i.e. they use electricity to generate other energy carriers). 
In Figs. 1-3 the transmission losses are incorporated in the flow "loss” to simplify the sankey diagram. This also applies to the heat flows.

$\beta$ Calculated as difference between the total primary supply and the sum of: electricity, fuel and 'nonenergy' use. The heat from district heating corresponded to $124 \mathrm{PJ}$; the remaining (174 PJ) is produced by combustion of fossil fuels and biomasses in boilers. 
Table 3 Distribution of energy consumption for transportation in 2030 and 2050 (PJ): E (electricity), BD (biodiesel), DS (diesel), PE (petrol), BE (bioethanol), SF (synthetic fuel), $\mathrm{CH}_{4}$ (methane) and $\mathrm{AF}$ (aviation fuel).

\begin{tabular}{|c|c|c|c|c|c|c|c|c|c|c|c|}
\hline \multirow[b]{2}{*}{ Transport } & \multicolumn{7}{|c|}{2030} & \multicolumn{4}{|c|}{2050} \\
\hline & E & $\mathrm{BD}$ & DS & $\mathrm{PE}$ & $\mathrm{BE}$ & $\mathrm{CH}_{4} / \mathrm{SF}$ & $\mathrm{AF}$ & $\mathrm{E}$ & $\mathrm{BD}$ & $\mathrm{CH}_{4} / \mathrm{SF}$ & $\mathrm{AF}$ \\
\hline $\begin{array}{l}\text { Passenger } \\
\text { cars }\end{array}$ & 10.7 & 1.3 & 5.7 & 27.5 & 4.7 & - & - & 17.1 & - & 5.1 & - \\
\hline Vans & 5.9 & 3.2 & 18.5 & - & - & - & - & 7.4 & - & 2.2 & - \\
\hline Buses & - & - & 9.1 & - & - & 0.8 & - & 0.9 & 5.7 & 1.1 & - \\
\hline Lorries & - & - & 33.6 & - & - & - & - & - & 25.2 & 3.4 & - \\
\hline $\begin{array}{l}\text { Passenger } \\
\text { trains }\end{array}$ & 6.6 & - & 0.2 & - & - & - & - & 16.9 & - & - & - \\
\hline $\begin{array}{l}\text { Freight } \\
\text { trains }\end{array}$ & 0.9 & - & & - & - & - & - & 1 & - & - & - \\
\hline $\begin{array}{l}\text { Domestic } \\
\text { aviation }\end{array}$ & - & - & - & - & - & - & 0.1 & - & - & - & 0.1 \\
\hline $\begin{array}{l}\text { International } \\
\text { aviation }\end{array}$ & - & - & - & - & - & - & 37.8 & - & - & - & 33.4 \\
\hline $\begin{array}{l}\text { Ship } \\
\text { transport }\end{array}$ & - & - & 2.8 & - & - & - & - & - & 1.8 & - & - \\
\hline Defence & - & - & 2.1 & - & - & - & - & - & 2.1 & - & - \\
\hline \multirow[t]{2}{*}{ Total } & 24.1 & 4.5 & 72 & 27.5 & 4.7 & 0.8 & 37.9 & 43.3 & 34.8 & 11.8 & 33.5 \\
\hline & \multicolumn{7}{|c|}{ (171.5) } & \multicolumn{4}{|c|}{ (123.4) } \\
\hline
\end{tabular}


Table 4 Overview of background data used for the LCA in relation to energy conversion technologies for selected Biomass-to-Energy (or -Fuel) processes: BtL (Biomass-to-

Liquid process), FT (Fischer-Tropsch), BE (bioethanol).

\begin{tabular}{|c|c|c|c|c|}
\hline Biomass & Energy technology & Products & Use of products \& byproducts & Reference \\
\hline Manure & $\begin{array}{l}\text { Anaerobic } \\
\text { digestion }\end{array}$ & $\begin{array}{l}\text { Biogas \& } \\
\text { digestate }\end{array}$ & $\begin{array}{l}\text { Biogas to heat \& electricity. Digestate to use on } \\
\text { land. }\end{array}$ & {$[27,32,33]$} \\
\hline Grass & $\begin{array}{l}\text { Anaerobic } \\
\text { digestion }\end{array}$ & $\begin{array}{l}\text { Biogas, solid } \\
\text { biofuel \& proteins }\end{array}$ & $\begin{array}{l}\text { Biogas to heat \& electricity. Grass fibers to heat \& } \\
\text { electricity. Proteins substitute soymeal. }\end{array}$ & [27] \\
\hline $\begin{array}{l}\text { Wood \& } \\
\text { willow }\end{array}$ & Gasification & Syngas \& biochar & Syngas to heat \& electricity. Biochar to use on land. & {$[27,51-53]$} \\
\hline Straw & Gasification & Syngas \& biochar & $\begin{array}{l}\text { Syngas to heat \& electricity. Biochar to use on } \\
\text { land. }\end{array}$ & {$[27,54]$} \\
\hline Waste & Incineration & Electricity \& heat & - & {$[27,55]$} \\
\hline Rapeseed & Transesterification & $\begin{array}{l}\text { RME, glycerin \& } \\
\text { solid biofuel }\end{array}$ & $\begin{array}{l}\text { RME to transport. Glycerin substitutes glycerin } \\
\text { production. Biofuel to heat \& electricity. }\end{array}$ & [27] \\
\hline $\begin{array}{l}\text { Willow } \\
\text { (BtL, FT) }\end{array}$ & $\begin{array}{l}\text { Gasification and } \\
\text { Fischer-Tropsch }\end{array}$ & $\begin{array}{l}\text { FT-biodiesel \& } \\
\text { biochar }\end{array}$ & FT-biodiesel for transport. Biochar to use on land. & [56] \\
\hline Straw (BE) & Straw refinery & $\begin{array}{l}\text { BE, molasses \& } \\
\text { solid biofuel }\end{array}$ & $\begin{array}{l}\text { Bioethanol for transport. Molasses substitutes } \\
\text { fodder. Biofuel to heat \& electricity. }\end{array}$ & {$[27,57]$} \\
\hline
\end{tabular}


Table 5 Overview of background data used for the LCA in relation to effects associated with direct land use changes (dLUC) for selected crops. Positive values indicate emissions (e.g. loss of carbon) while negative values indicate sequestration ( $1 \mathrm{ha}=10^{4}$ $\mathrm{m}^{2}$ ).

\begin{tabular}{lrrrr}
\hline Crop & $\mathrm{Mg} \mathrm{CO}_{2} / \mathrm{ha}$ & $\mathrm{Mg} \mathrm{N}_{2} \mathrm{O} / \mathrm{ha}$ & $\mathrm{Mg} \mathrm{NO}_{3} / \mathrm{ha}$ & Reference \\
\hline Barley & 84 & 0.02 & 4.6 & [30] \\
Rapeseed & 88 & 0.022 & 4.6 & {$[30]$} \\
Willow & -0.12 & 0.0026 & 2.3 & [28] \\
\hline
\end{tabular}


Table 6 Overview of energy supply in the individual energy scenarios (fossil fuel and total primary energy supply) and of environmental impacts: 1) normalized per primary energy supply, 2) total impacts for each scenario, and 3) potential totals assuming that primary energy supply was identical to the reference year 2008 (864 PJ).

\begin{tabular}{|c|c|c|c|c|c|c|c|c|}
\hline & & & \multirow{2}{*}{ Unit } & \multicolumn{5}{|c|}{ Energy system } \\
\hline & & & & 2008 & 2030 & 2050CSV & 2050RME & 2050BtL \\
\hline & \multicolumn{8}{|l|}{ Energy supply: } \\
\hline & \multicolumn{2}{|l|}{ Fossil fuel } & PJ & 704 & 283 & 87 & 40 & 40 \\
\hline & \multicolumn{2}{|l|}{ Primary energy (total) } & $\mathrm{PJ}_{\mathrm{PES}}$ & 864 & 679 & 559 & 576 & 588 \\
\hline \multirow{15}{*}{ 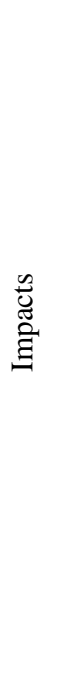 } & \multirow{4}{*}{ GW } & Normalized & $\mathrm{Gg} \mathrm{CO}_{2}$-eq $/ \mathrm{PJ}_{\mathrm{PES}}$ & 68 & 38 & 20 & 31 & 17 \\
\hline & & Total & $\mathrm{Tg} \mathrm{CO}_{2}$ & 59 & 26 & 11 & 18 & 10 \\
\hline & & Total REF & $\operatorname{Tg} \mathrm{CO}_{2}$ & 59 & 33 & 17 & 27 & 15 \\
\hline & & Normalized & $10^{4} \mathrm{~m}^{2} / \mathrm{PJ}_{\mathrm{PES}}$ & 301 & 193 & 121 & 177 & 135 \\
\hline & \multirow[t]{2}{*}{ AC } & Total & $10^{7} \mathrm{~m}^{2}$ & 260 & 130 & 68 & 100 & 79 \\
\hline & & Total REF & $10^{7} \mathrm{~m}^{2}$ & 260 & 167 & 105 & 153 & 117 \\
\hline & \multirow{4}{*}{$\operatorname{EP}(\mathbf{N})$} & Normalized & $\mathrm{Mg} \mathrm{N} / \mathrm{PJ}_{\mathrm{PES}}$ & 14 & 16 & 15 & 29 & 24 \\
\hline & & Total & Gg N & 12 & 11 & 8.4 & 17 & 14 \\
\hline & & Total REF & Gg N & 12 & 14 & 13 & 25 & 21 \\
\hline & & Normalized & $\mathrm{Mg} \mathrm{P} / \mathrm{PJ}_{\mathrm{PES}}$ & 0.1 & 2.0 & 2.4 & 3.9 & 2.8 \\
\hline & \multirow[t]{3}{*}{ EP (P) } & Total & Gg P & 0.1 & 1.3 & 1.3 & 2.3 & 1.7 \\
\hline & & Total REF & Gg P & 0.1 & 1.7 & 2.1 & 3.4 & 2.4 \\
\hline & & Normalized & $10^{4} \Delta \mathrm{m}^{2} / \mathrm{PJ}_{\mathrm{PES}}$ & - & 624 & 861 & 2089 & 1787 \\
\hline & \multirow{2}{*}{ LO } & Total & $10^{7} \Delta \mathrm{m}^{2}$ & - & 420 & 480 & 1200 & 1100 \\
\hline & & Total REF & $10^{7} \Delta \mathrm{m}^{2}$ & - & 539 & 744 & 1805 & 1544 \\
\hline
\end{tabular}


Table 7 Results of the sensitivity analysis expressed as net differences ' $\Delta$ ' compared with the baseline result as presented in Figure 4. Units are $\Delta \mathrm{Gg} \mathrm{CO}_{2}$-eq/PJ $\mathrm{PES}_{\mathrm{PES}}(\mathrm{GW})$, $10^{4} \Delta \mathrm{m}^{2} / \mathrm{PJ}$ (AC), $\Delta \mathrm{Mg} \mathrm{N} / \mathrm{PJ}_{\mathrm{PES}}(\mathrm{EP}(\mathrm{N})), \Delta \mathrm{Mg} \mathrm{P} / \mathrm{PJ}_{\mathrm{PES}}\left(\mathrm{EP}(\mathrm{P})\right.$ ), and $\left.10^{4} \Delta \mathrm{m}^{2} / \mathrm{PJ}_{\mathrm{PES}}\right)$. The sensitivity analysis for RME (2) and biochar (4) only affected the GW category (y: yield; $\eta$ : efficiency; $\uparrow$ : increase; $\downarrow$ : decrease).

\begin{tabular}{llrrr}
\hline Category & Parameter & 2050CSV & 2050RME & 2050BtL \\
\hline \multirow{2}{*}{ GW } & $(1)$ Willow $(\mathrm{y} \uparrow / \mathrm{y} \downarrow)$ & $-1 /+2$ & $-1 /+2$ & $-2 /+4$ \\
& $(2)$ RME $(\mathrm{iLUC} \downarrow)$ & - & -11 & - \\
& $(3)$ BtL $(\eta \uparrow)$ & - & - & -1 \\
& $(4)$ Biochar $(\downarrow)$ & +2 & +2 & +4 \\
\hline \multirow{2}{*}{ AC } & $(1)$ Willow $(y \uparrow / \mathrm{y} \downarrow)$ & $-1.6 /+4$ & $-1.6 /+4$ & $-5 /+7$ \\
& $(3)$ BtL $(\eta \uparrow)$ & - & - & -2 \\
\hline \multirow{2}{*}{ EP (N) } & $(1)$ Willow $(\mathrm{y} \uparrow / \mathrm{y} \downarrow)$ & $-1 /+2.5$ & $-1 /+2.5$ & $-3 /+4.5$ \\
& $(3)$ BtL $(\eta \uparrow)$ & - & - & -1 \\
\hline \multirow{2}{*}{ EP (P) } & $(1)$ Willow $(\mathrm{y} \uparrow / \mathrm{y} \downarrow)$ & $-0.1 /+0.2$ & $-0.1 /+0.2$ & $-0.2 /+0.5$ \\
& $(3)$ BtL $(\eta \uparrow)$ & - & - & -0.1 \\
\hline \multirow{2}{*}{ LO } & $(1)$ Willow $(y \uparrow / y \downarrow)$ & $-60 /+440$ & $-60 /+440$ & $-445 /+630$ \\
& $(3)$ BtL $(\eta \uparrow)$ & - & - & -100 \\
\hline
\end{tabular}




\section{List of Figures}

Figure 1 Energy system “2008” (unit: PJ). The energy consumption of the offshore platforms for oil and gas extraction is included in the energy system. BM: biomass, PV: photovoltaic, hydro: hydropower, CO: coal, NG: natural gas, E: electricity, H: heat, L: losses, BP: byproducts, F: fuel.

Figure 2 Energy system “2030” (unit: PJ). The energy consumption of the offshore platforms for oil and gas extraction is included in the energy system. GH: geothermal heat, ST: solar thermal, PV: photovoltaic, Hydro: hydropower, CO: coal, NG: natural gas, Syn: syngas, BG: biogas, E: electricity, H: heat, L: losses, BP: byproducts, PE: petrol, DS: diesel, BD: biodiesel, AF: aviation fuel, SF: synthetic fuel

Figure 3 Energy system “2050CSV”, “2050RME” and “2050BtL” (unit: PJ). The energy consumption of the offshore platforms for oil and gas extraction is included in the energy system. GH: geothermal heat, ST: solar thermal, PV: photovoltaic, Hydro: hydropower, CO: coal, NG: natural gas, Syn: syngas, BG: biogas, E: electricity, H: heat, L: losses, BP: byproducts, PE: petrol, DS: diesel, BD: biodiesel, AF: aviation fuel, SF: synthetic fuel

Figure 4 Contribution of the different sub-processes to the impact on the selected environmental categories

Figure 5 Environmental impacts associated with the production of biodiesel (and diesel) for heavy transportation (functional unit: 1 PJ diesel-fuel). *Excluding potential environmental benefits associated with the use of biochar residual from gasification processes 


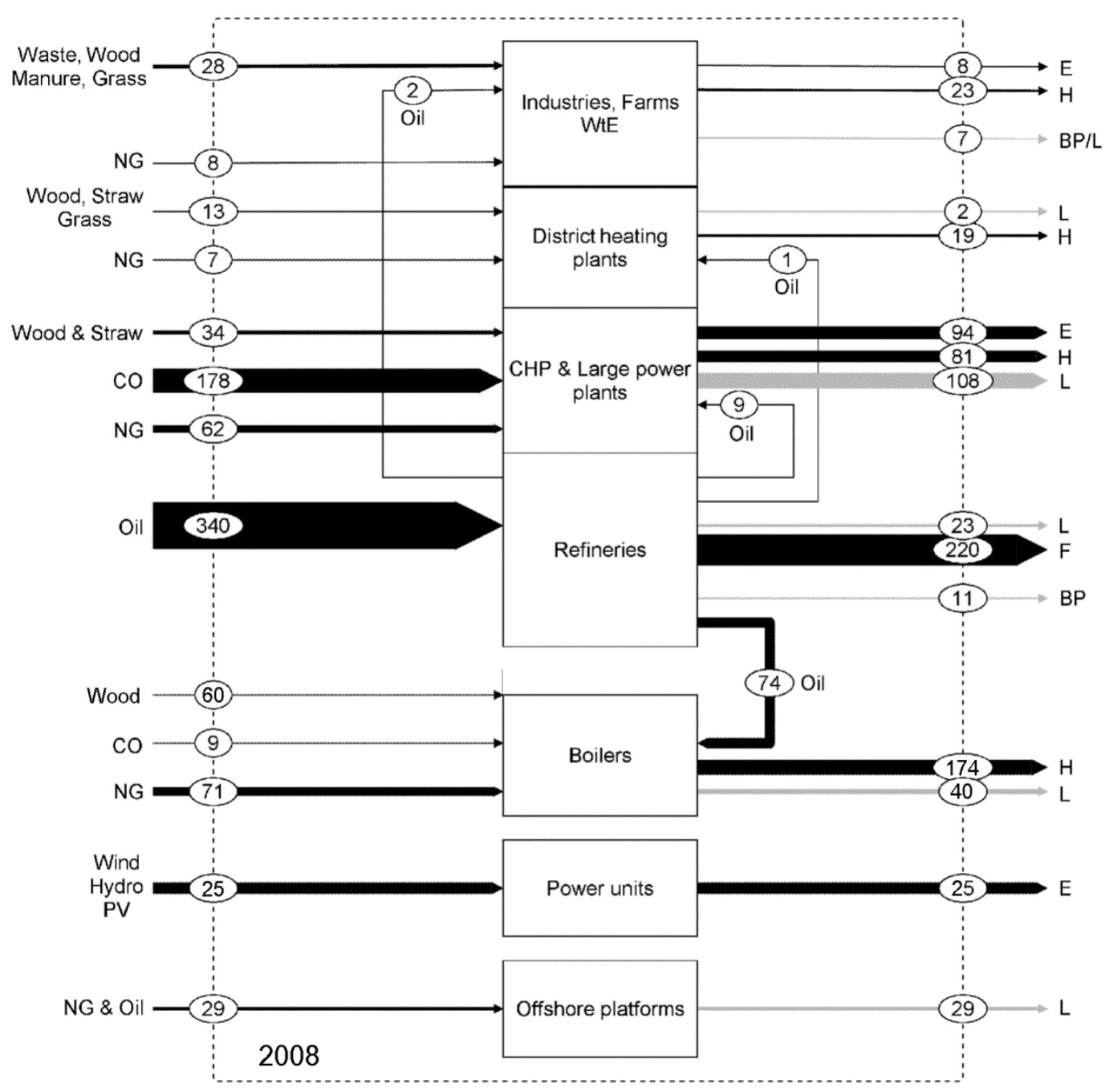

Figure 1 


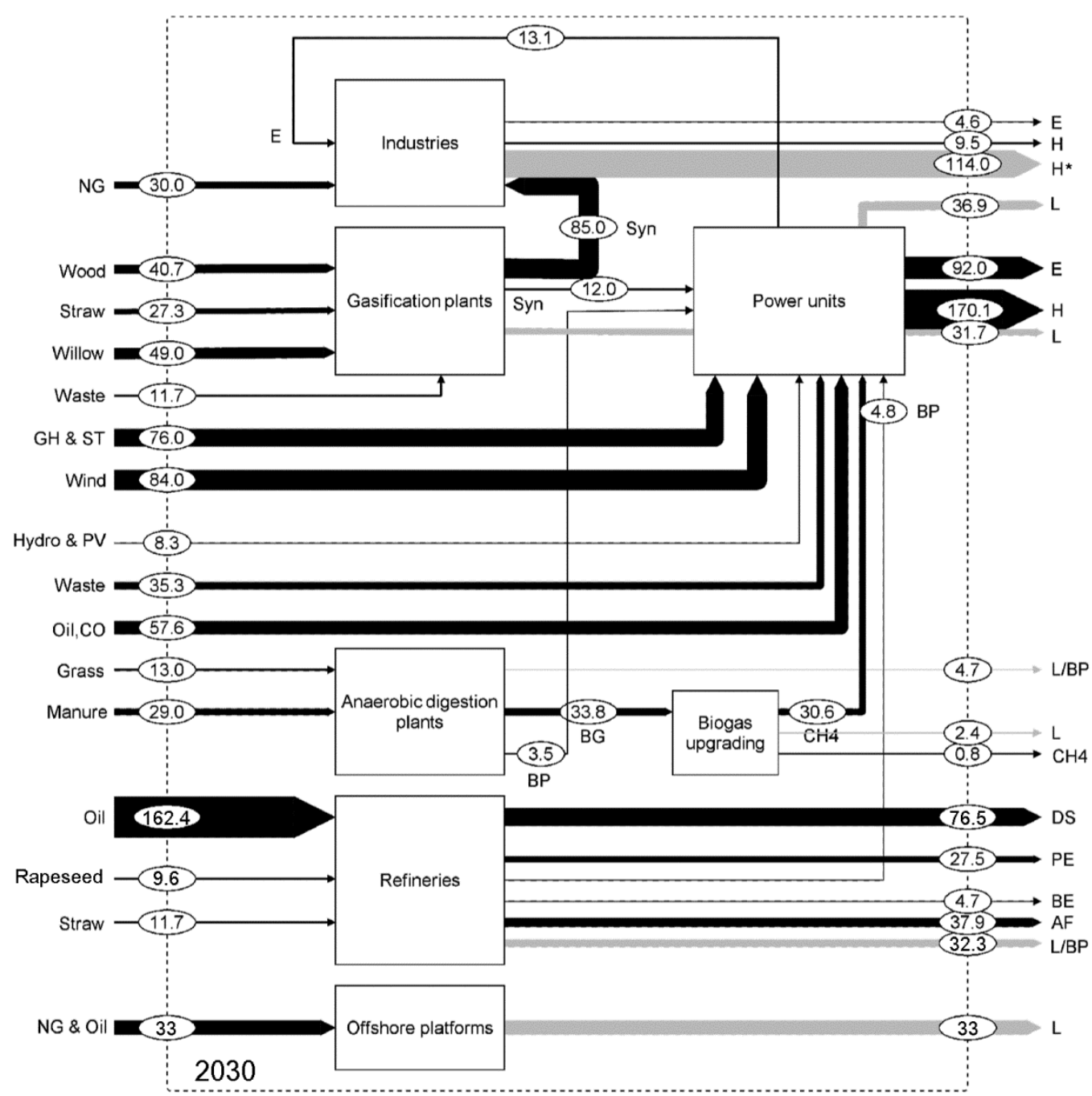

Figure 2 


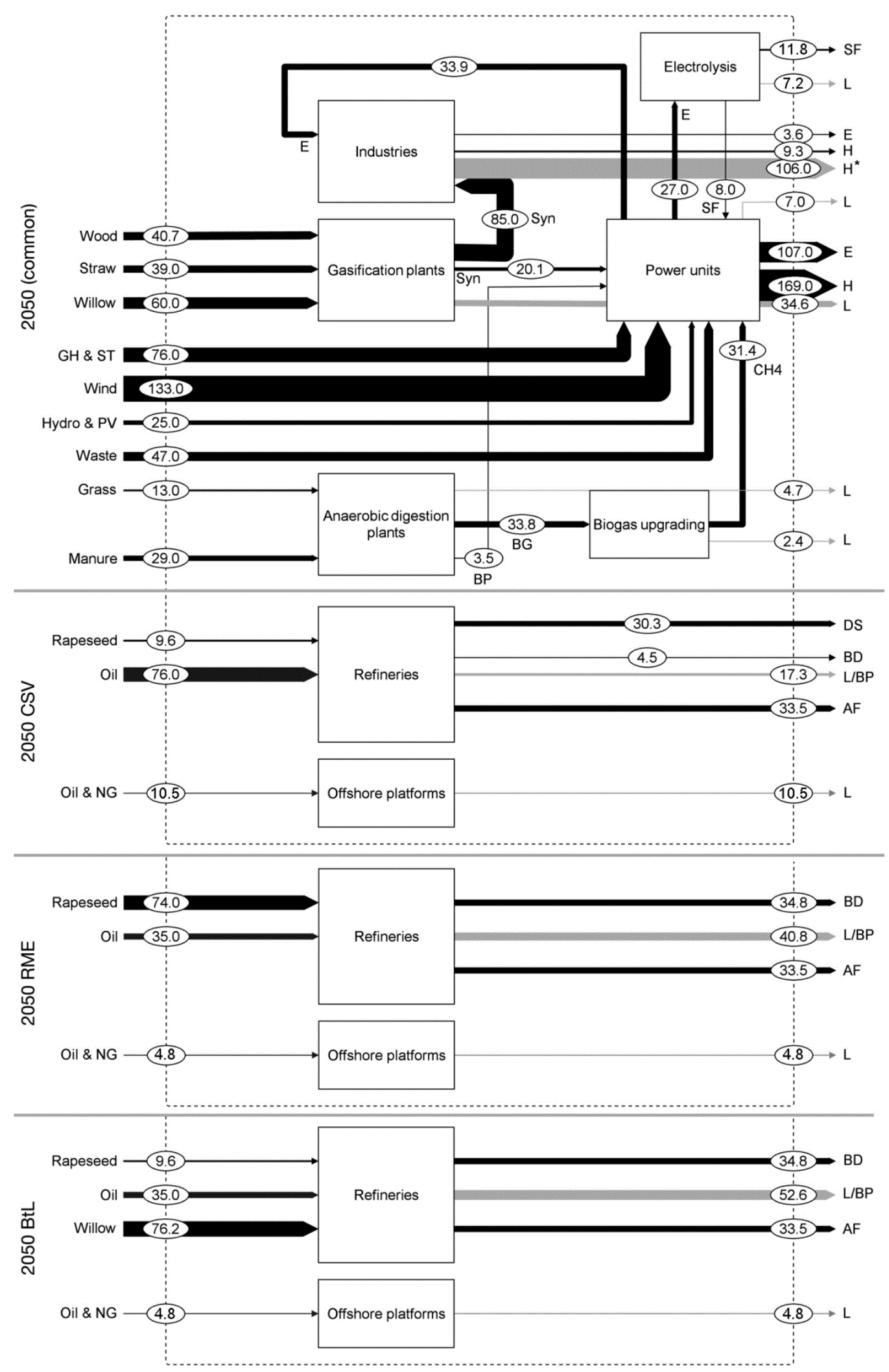

Figure 3 

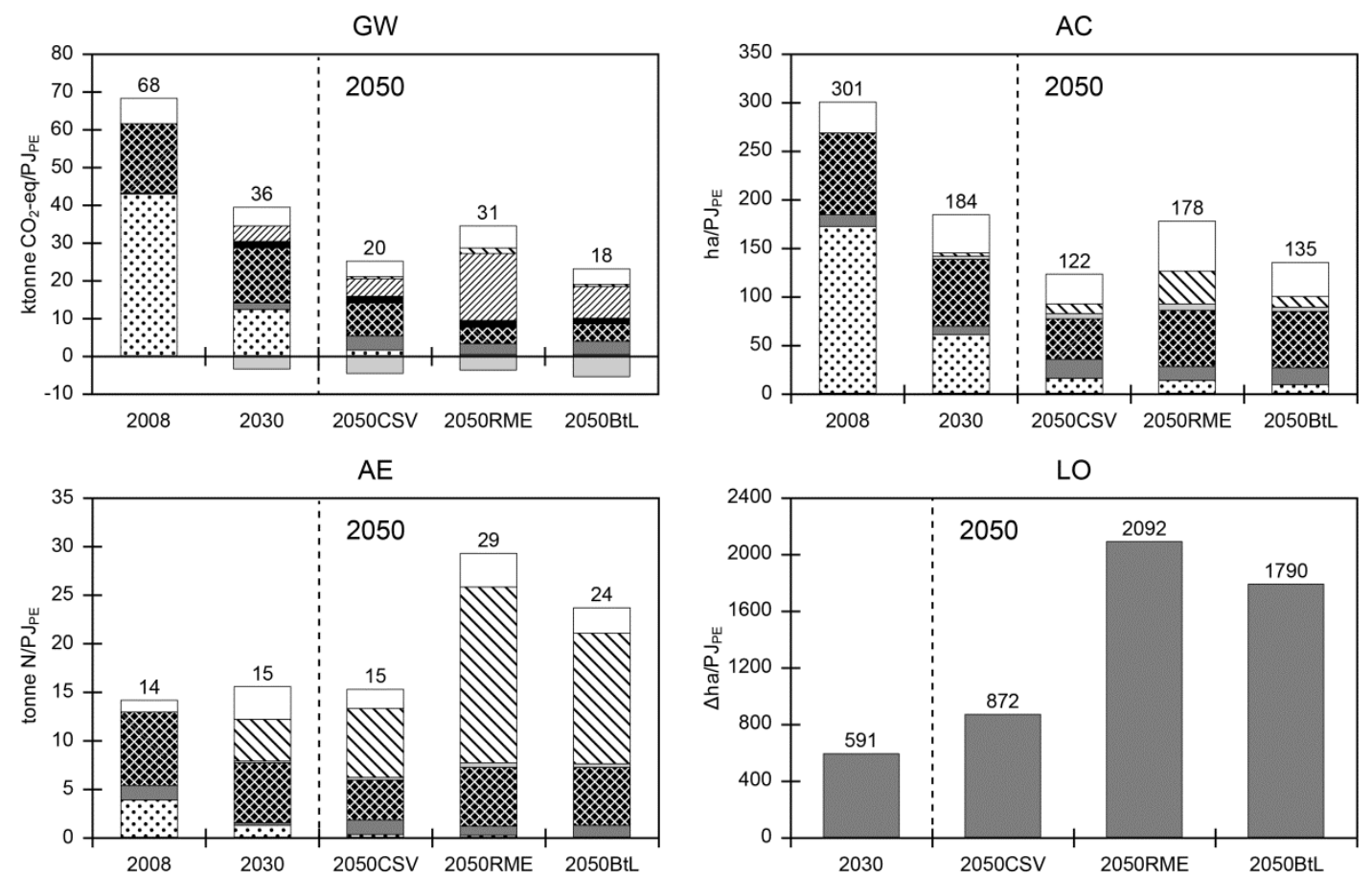

\begin{tabular}{|llll|}
\hline$\because$ Fossil fuel combustion (PP) & $\square$ LUC & Transportation & $\square$ Straw management \\
$\square$ Biofuel combustion (PP) & $\square$ Management of BtE residuals & $\nabla$ Crop cultivation & $\square$ Other \\
\hline
\end{tabular}

Figure 4 

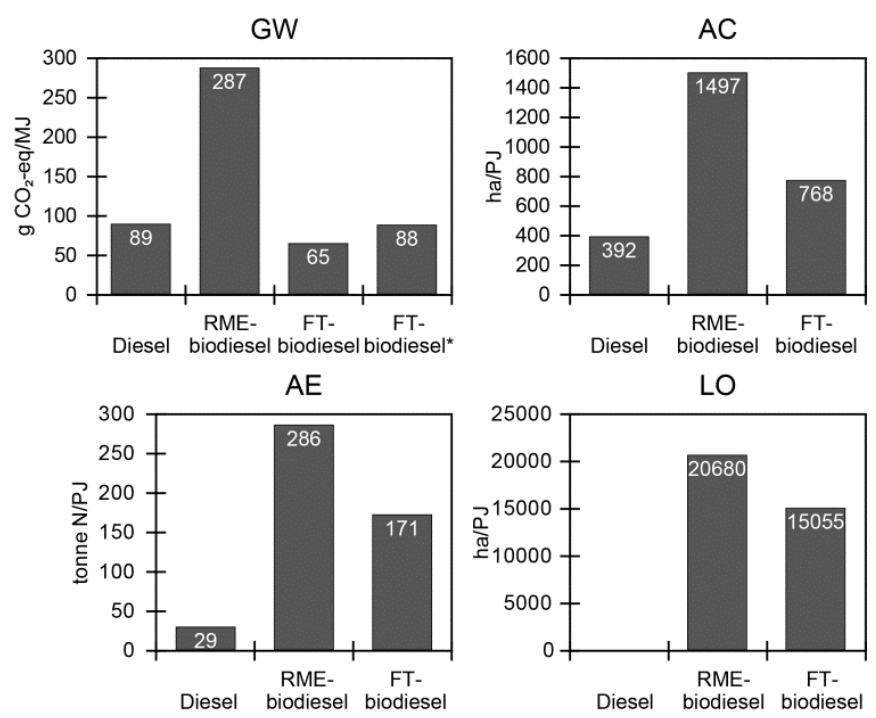

Figure 5 
Supporting Information for:

“LCA of biomass-based energy systems: a case study for Denmark”

Tonini, D.* \& Astrup, T.

Technical University of Denmark, Department of Environmental Engineering

*Corresponding author email: dait@env.dtu.dk

This supporting information document includes text and tables with details on the process data for the inventory analysis of the LCA.

SI.1 Biomass resources

SI.2 Energy conversion technologies

SI.3 Land use changes (LUC)

SI.4 Management of agricultural and biomass conversion residuals 


\section{SI.1 Biomass resources}

Relevant biomasses resources available in Denmark (Table S1) were: manure, grass, lignocellulosic biomass, waste, beet top, molasses, whey, potato pulp, brewer's grain. With respect to the straw, today only $41 \%$ and $15 \%$ of straw from corn, barley and rape (not used for feeding or bedding) is used for energy production. The remaining is ploughed back to the field. According to [1], if $100 \%$ removal and utilization was assumed the total potential of corn, barley and rape derived straw would be about 39 PJ. In this study a straw potential of 39 PJ was assumed. The environmental consequences of straw removal were included in the LCA.

The estimates behind the data reported for energy crops (9.1 PJ) were based on the assumption that $50 \%$ of the land currently "lying fallow" can be used for energy crops, such as willow or Miscanthus [1]. The remaining 50\% of land was considered unsuitable for crop cultivation as the soil quality was poor. These low-lying areas were instead assumed suitable for cultivation of grass. All of this grass (100\% exploitation) was assumed utilized for biogas production yielding about 6.8 PJ of biogas. The overall energy potential of grass was estimated equal to about 13 PJ based on a HHV of $18 \mathrm{GJ} / \mathrm{Mg} \mathrm{DM}$ and on a biogas yield of $400 \mathrm{Nm}^{3} / \mathrm{Mg}$ DM. This was done in order to include the energy potential of the fibers residue (i.e. solid biofuel to be combusted) left after anaerobic digestion. The consequences of less grass available for feeding were included in the LCA.

Waste quantities were predicted to increase to $47 \mathrm{PJ}$ in 2030, following the trends from previous years. From 2030 to 2050 no increase was included, assuming that the share of recycling increases thereby leaving less waste available for energy purposes. Waste quantities only included waste which is today used for energy purposes. In this study, beet top, molasses, whey, potato pulp and brewer's grain were disregarded because these resources are today for animal feeding and/or bedding and because of the relatively small energy potential associated with these specific resources.

The total quantities of residual domestically available biomass resources (182.3 PJ) did not match the energy demand in the future scenarios, therefore cultivation of energy crops had to be considered. Additional 40 and 51 PJ of willow (i.e. on the top of the 9.1 PJ domestically available) respectively for the “2030” and “2050” scenarios were estimated to be required in order to fulfill the needed electricity and heat demand (modeled in [2-4]). Willow was selected as a favorable energy crop among the others (e.g. Miscanthus, poplar etc.) because of the high 
yield, low requirement of fertilizers and other agricultural practices, capacity of sequestering carbon, adaptability to different soils etc. [5,6]. However, the choice of Miscanthus or other short rotation coppice (SRC) would not affect the results, as yield and fertilizers needs for these crops are similar [6]. Rapeseed was selected as oil crop for production of biodiesel, as rapeseed cultivation is already practiced in Denmark and because of lower environmental impacts compared with the cultivation of soy.

Table S1 Overview of the biomass potential for Denmark. The values are expressed as primary energy (LHV) before energy conversion, except of manure and grass (in brackets) for which potentials are expressed as energy in the biogas. U: in use; P: potential.

\begin{tabular}{|c|c|c|c|c|c|c|}
\hline Biomass (PJ) & U [7] & $\mathrm{P}[7]$ & U [8] & $\mathrm{P}[8]$ & $\mathrm{P}[1]$ & $\mathrm{P}$ (this study) \\
\hline rapeseed & 3.4 & 4.5 & - & - & 4.5 & 4.5 \\
\hline willow & 0.5 & 9.1 & - & - & 9.1 & 9.1 \\
\hline grass & 0 & 5.1 & - & - & 5.1 & $13(6.8)^{*}$ \\
\hline straw & 18.5 & 26.8 & 17.3 & 26.8 & 33.5 & 39 \\
\hline beet top & - & & - & - & 0.2 & - \\
\hline animal manure & 1.1 & 20.2 & - & - & 20.2 & 27 \\
\hline fiber fraction & 0 & 2.5 & - & - & 2.5 & 2 \\
\hline mill residues & - & - & - & - & 0.9 & - \\
\hline beet pulp & - & - & - & - & 1.7 & - \\
\hline molasses & - & - & - & - & 1.2 & - \\
\hline potato pulp & - & - & - & - & 0.3 & - \\
\hline brewer's grain & - & - & - & - & 0.6 & - \\
\hline whey & - & - & - & - & 2.8 & - \\
\hline wood chips & - & - & 9.8 & & 7.7 & 9.8 \\
\hline fire wood & - & - & 23 & & 26 & 23 \\
\hline unexploited forest increment & - & - & - & 40 & 17 & - \\
\hline wood pellets & - & - & 2.3 & & 2.6 & 2.3 \\
\hline wood residues & - & - & 5.6 & & 6.3 & 5.6 \\
\hline waste & - & - & 23 & $34-41$ & - & 47 \\
\hline paper and cardboard & - & - & 5-6 & 5-6 & - & - \\
\hline industrial waste & 0.9 & 1.5 & - & - & - & - \\
\hline animal fat & 1.9 & 3.2 & - & - & - & - \\
\hline meat and bones & 0 & 1.6 & - & - & - & - \\
\hline Total & & & & & 142.2 & 182.3 \\
\hline
\end{tabular}

\section{SI.2 Energy conversion technologies}

The choice of the Biomass-to-Energy (BtE) conversion technologies was based on the following considerations which implied energy system as well as technical issues for handling the biomasses. 
Future energy systems in Denmark will have to face the challenge of integrating high shares of fluctuating energy sources, such as wind power, into the energy system. In order to reach this goal more flexible biomass conversion technologies are needed to accommodate the fluctuations [9]. Production of intermediate energy carriers (e.g. syngas or biogas) may therefore be favorable to direct combustion of biomass, at least in those cases where the overall conversion efficiency is competitive with direct combustion. Anaerobic digestion for biogas production is already widely applied in Denmark [10]. With respect to lignocellulosic biomass, thermal gasification is a promising technology for conversion to gas with as high as $90 \%$ cold gas efficiencies (CGE), e.g. [11-13]. As minimization of transport distances is important, installation of local small-scale facilities for conversion of biomass should be preferred over centralized plants (provided efficiencies are competitive). Thermal gasifiers have been demonstrated to be competitive with combustion plants at a small-scale (100-600 kWe) [11-15]. Lignocellulosic biomass was therefore assumed gasified for production of syngas with efficiencies as reported in Table S3. Production of biochar was estimated to $20 \mathrm{~kg} / \mathrm{Mg}$ lignocellulosic biomass [16]. Biochar was assumed to be returned to soil and the energy system was credited for the carbon sequestration and other benefits (see further sections).

Manure as well as grass was assumed to be fermented to biogas through anaerobic digestion with efficiencies as reported in Table S2. Manure was assumed to be separated into a liquid and solid fraction through centrifugal separation combined with addition of cationic polymer [17-20]. The solid fraction was then added to raw manure to boost biogas production. Overall, such process increased $\mathrm{N}$ and $\mathrm{P}$ availability in the residual digestate after anaerobic digestion [17,18]. With respect to grass, the multiple-output grass-refinery process [21] generated biogas (500 $\mathrm{Nm}^{3} / \mathrm{Mg} \mathrm{DM}$ grass), grass fibers ( $0.4 \mathrm{Mg} / \mathrm{Mg} \mathrm{DM}$ grass) and proteins ( $0.15 \mathrm{Mg} / \mathrm{Mg} \mathrm{DM}$ grass). The grass fibers were assumed to be combusted in cogeneration plants producing electricity and heat [22]. The proteins were assumed to substitute for soy meal. The substitution ration was: $1 \mathrm{~kg}$ of proteins substituted for $1 \mathrm{~kg}$ of soy meal based on the proteins content. Syngas and biogas were assumed used in Solid Oxide Fuel Cells (SOFC) after upgrading to natural gas quality (electricity efficiency $54 \%$ and heat efficiency $36 \%$ ). Solid waste was assumed combusted in waste incinerators with electricity and heat efficiencies of $25 \%$ and 70\%, respectively (typical values for Danish incinerators) [23]. 
Rapeseed was assumed converted into Rape Methyl Ester (RME) through a transesterification process in modern biorefineries [21]. The relevant process outputs from $1 \mathrm{Mg}$ of rapeseed were: RME (0.35 Mg), rape meal (0.6 Mg) and glycerin (0.038 Mg). $1 \mathrm{~kg}$ rape meal was assumed to substitute soybean $(0.76 \mathrm{~kg})$ and spring barley $(0.11 \mathrm{~kg})$ [24]. $1 \mathrm{~kg}$ glycerin was assumed to substitute glycerin produced from fossil resources on a 1:1 ratio. The "2030" scenario involved production of bioethanol from straw [25,26] with the following outputs per Mg DM straw: ethanol (0.21 Mg), C5 molasses (0.254 Mg, 30\% water content) and solid biofuel (0.35 Mg, 10\% water content). Molasses were assumed to substitute spring barley (0.96 kg) [26]. Production of biodiesel through the Biomass-to-Liquid pathway (BtL) was assumed to be based on Fischer-Tropsch technology and processes [27]. Overall Biomass-to-Liquid conversion efficiencies depended on process configurations and biomass types but varied between 35\% (electricity is cogenerated) and 57\% (maximum fuel production) for lignocellulosic biomasses. A gross Biomass-to-Liquid conversion efficiency of $45 \%$ was assumed. The processes required for FT-biodiesel production were: gasification of biomass, gas cleaning, gas conditioning and compression, Fischer-Tropsch synthesis and final refinery. Electricity consumption was 0.035 kWh/MJ FT-diesel (gasification), 0.066 kWh/MJ FT-diesel (gas cleaning), 0.013 kWh/MJ FTdiesel (gas conditioning and compression), 5E-06 kWh/MJ FT-diesel (Fischer-Tropsch). For the final refinery, common processes for fossil fuels refining found in the Ecoinvent database [27] were used. The electricity consumption in modern refineries is about $0.001 \mathrm{kWh} / \mathrm{MJ}$ products. The production of FT-diesel through thermochemical conversion is thus a very energy intensive process and the extra electricity and heat required in the system compared with traditional refinery of fossil fuel was accounted for as diminished efficiency (i.e. as extra consumption of biomass in the process). The overall efficiency of the BtL process (accounting for the extra biomass) was about $40 \%$.

With respect to the LCIs for wind, hydro and wave power, heat pumps, SOFC, fossil fuel combustion in combined heat and power (CHP) plants, district heating plants, peak-load boilers, vehicles, offshore platforms, electrolysis units and industrial furnaces for heat production, common processes found in the Ecoinvent database were used. 
Table S2 Biogas (or $\mathrm{CH}_{4}$ ) potential of anaerobic digestion technologies for grass and manure (FM=fresh matter; DM=dry matter; VS=volatile solids).

\begin{tabular}{|c|c|c|c|c|c|}
\hline Biomass & Unit & Value & Source & Note & This study \\
\hline \multirow{3}{*}{ Manure } & $\mathrm{Nm}^{3} / \mathrm{Mg} \mathrm{FM}$ & 27.7 & {$[17,18]$} & LCA slurry management & \multirow{3}{*}{$28 \mathrm{Nm}^{3} / \mathrm{Mg} \mathrm{FM}$} \\
\hline & $\mathrm{Nm}^{3} / \mathrm{Mg} \mathrm{FM}$ & 22 & [28] & Data from Danish plants & \\
\hline & $\mathrm{Nm}^{3} / \mathrm{Mg} \mathrm{FM}$ & 19.8 & {$[21]$} & Data from Swiss plants & \\
\hline \multirow{6}{*}{ Grass } & $\mathrm{Nm}^{3} / \mathrm{Mg} \mathrm{DM}$ & 299-1080 & [29] & Review & \multirow{6}{*}{$400 \mathrm{Nm}^{3} / \mathrm{Mg} \mathrm{DM}$} \\
\hline & $\mathrm{Nm}^{3} / \mathrm{Mg} \mathrm{DM}$ & 210 & {$[21]$} & Grass biorefinery & \\
\hline & $\mathrm{Nm}^{3} / \mathrm{Mg} \mathrm{FM}$ & 21 & [30] & Estimation & \\
\hline & $\mathrm{Nm}^{3} / \mathrm{Mg} \mathrm{FM}$ & 211 & [31] & Pilot-scale fermentation & \\
\hline & $\mathrm{Nm}^{3} \mathrm{CH}_{4} / \mathrm{Mg} \mathrm{VS}$ & $230-350$ & [32] & LCA/energy analysis & \\
\hline & $\mathrm{Nm}^{3} / \mathrm{Mg} \mathrm{VS}$ & 600 & [33] & Lab-test (mesophilic) & \\
\hline \multirow{2}{*}{ Willow } & $\mathrm{Nm}^{3} / \mathrm{Mg} \mathrm{VS}$ & 360 & [34] & Pretreatment (wet oxidation) & \multirow{2}{*}{ - } \\
\hline & $\mathrm{Nm}^{3} / \mathrm{Mg} \mathrm{VS}$ & 200 & [34] & Without pretreatment & \\
\hline \multirow{2}{*}{ Mischantus } & $\mathrm{Nm}^{3} / \mathrm{Mg} \mathrm{VS}$ & 360 & [34] & Pretreatment (wet oxidation) & - \\
\hline & $\mathrm{Nm}^{3} / \mathrm{Mg} \mathrm{VS}$ & 200 & [34] & Without pretreatment & \\
\hline
\end{tabular}

Table S3 Cold Gas Efficiency (CGE, i.e. ration between the energy transferred into the produced gas and the energy in the biomass, as LHV dry basis) of thermal gasification technologies from different literature studies.

\begin{tabular}{|c|c|c|c|c|}
\hline Biomass & CGE & Source & Note & This study \\
\hline \multirow{6}{*}{ Woodchips } & 0.93 & {$[12]$} & Pilot-scale 2-stage fixed bed & \multirow{6}{*}{0.93} \\
\hline & 0.74-0.92 & {$[16]$} & Pilot-scale fluidised bed & \\
\hline & 0.8 & [35] & Pilot-scale fluidised bed & \\
\hline & 0.648 & {$[36]$} & Lab-scale fixed bed & \\
\hline & 0.714 & [37] & Lab-scale circulating fluidised bed & \\
\hline & $0.8-0.92$ & [38] & Review & \\
\hline Wood pellets & 0.96 & [38] & Review & 0.93 \\
\hline \multirow{2}{*}{ Wood waste } & 0.82 & [39] & Review & \multirow{2}{*}{0.85} \\
\hline & $0.49-0.66$ & {$[35]$} & Pilot-scale fluidised bed & \\
\hline \multirow{3}{*}{ Wood sawdust } & 0.605 & [40] & Pilot-scale circulating fluidised bed & \multirow{3}{*}{-} \\
\hline & 0.569 & {$[41]$} & Lab-scale fluidised bed & \\
\hline & 0.57 & {$[38]$} & Review & \\
\hline \multirow{3}{*}{ Straw } & 0.85 & [42] & Pilot-scale 2-stage fixed bed & \multirow{3}{*}{0.85} \\
\hline & 0.85 & {$[39]$} & Review & \\
\hline & 0.81 & {$[16]$} & Pilot-scale fluidised bed & \\
\hline \multirow{3}{*}{ Mischantus } & 0.4 & [43] & Lab-scale circulating fluidised bed & \multirow{3}{*}{-} \\
\hline & $0.3-0.53$ & [44] & Lab-scale fixed bed & \\
\hline & 0.85 & [39] & Review & \\
\hline \multirow{2}{*}{ Willow } & $0.25-0.43$ & {$[44]$} & Lab-scale fixed bed & \multirow{2}{*}{0.9} \\
\hline & 0.85 & [39] & Review & \\
\hline
\end{tabular}




\section{SI.3 Land use changes (LUC)}

Cultivation of energy crops required use of land thereby inducing direct and indirect land use changes (dLUC and iLUC) under the basic assumption that land available for cultivation is constrained. A brief review of dLUC impacts is reported in Table S4. The iLUC are discussed in the following.

With respect to willow, the direct land use changes were estimated based on [45] which estimated the soil organic carbon (SOC) changes related to the conversion of different types of land into SRC. No carbon losses were estimated for conversion of grassland (or set-aside land) into SRC. Instead, increases in carbon stock were estimated when converting arable land into SRC (0-115 kg C/ha depending on the type of tillage for wheat. i.e. reduced or conventional). The indirect land use changes were estimated based on the assumption that expansion of willow cultivated land in Denmark replaced the marginal crop (spring barley) which had to be produced somewhere else if status quo was to be maintained [46,47]. The most likely consequence was assumed to be conversion of grassland into barley (69\%) as well as intensification of barley cultivation in Canada $(31 \%)[46,48,49]$. The land use consequence of replacing prairie grass with barley was $84 \mathrm{Mg} \mathrm{CO} / \mathrm{ha}$. Given the assumed yield of willow (11.8 Mg DM/ha) and barley in Denmark and Canada (respectively, 5.2 Mg and 2.8 Mg DM/ha), this corresponded to an iLUC emission of about $1.5 \mathrm{~kg} \mathrm{CO} / \mathrm{kg}$ barley cultivated in Canada on converted land. Instead, intensification finally implied a larger utilization of fertilizers in order to increase the production on the same constrained land. According to [49] this led to an increase if $\mathrm{N}$-fertilizer use of about $1 \mathrm{~kg} \mathrm{~N} / \mathrm{ha}$ (for Canadian conditions). According to [1], the potential for energy crops cultivation in Denmark corresponded to 9.1 PJ. The current production (2009) was 0.5 PJ. It was therefore assumed that 8.6 PJ of willow were cultivated on Danish set-aside land implying negligible SOC (hence negligible dLUC) whereas the remaining amount required to satisfy the energy demand was instead cultivated at the expenses of the marginal crop (spring barley) implying both dLUC in Denmark and iLUC in Canada, as explained previously.

With respect to rapeseed, direct and indirect land use changes were quantified according to [48] assuming conversion of set-aside land into rapeseed (all 2050 scenarios) or conversion of set-aside land and arable land (spring barley) into rapeseed (only the "2050RME” scenario). For the conversion of set-aside land to rapeseed in Denmark an emission of $88 \mathrm{Mg} \mathrm{CO}_{2} / \mathrm{ha}(4.4 \mathrm{Mg}$ $\left.\mathrm{CO}_{2} / \mathrm{ha} / \mathrm{y}\right), 0.022 \mathrm{Mg} \mathrm{N}{ }_{2} \mathrm{O} / \mathrm{ha}\left(0.001 \mathrm{Mg} \mathrm{N} \mathrm{N}_{2} \mathrm{O} / \mathrm{ha} / \mathrm{y}\right)$ and $4.6 \mathrm{Mg} \mathrm{NO}_{3} / \mathrm{ha}\left(0.23 \mathrm{Mg} \mathrm{NO}_{3} / \mathrm{ha} / \mathrm{y}\right)$ 
was assumed. For conversion of arable land (spring barley) to rapeseed, a carbon loss of 0.115 $\mathrm{Mg} \mathrm{C/ha/y} \mathrm{was} \mathrm{assumed} \mathrm{according} \mathrm{to} \mathrm{[45].} \mathrm{Only} \mathrm{dLUC} \mathrm{and} \mathrm{iLUC} \mathrm{associated} \mathrm{with} \mathrm{changes} \mathrm{in}$ rapeseed cultivation from the current situation to the future needs were considered. The methodology as well as the final estimations of iLUC was characterized by significant uncertainty. This uncertainty has been addressed in the sensitivity analysis. 
Table S4 Effects of direct land use changes (dLUC) on the soil organic carbon from different literature studies (SRC: short rotation coppice; OSR: oilseed rape). Negative values indicate emissions (e.g. loss of carbon), positive values indicate sequestration.

\begin{tabular}{|c|c|c|c|c|c|}
\hline Crop & Unit & Value & Note & Source & This study \\
\hline \multirow{3}{*}{ Barley } & $\mathrm{Mg} \mathrm{CO}_{2} / \mathrm{ha}$ & -84 & Prairie grass to cropland & [48] & \multirow{3}{*}{ [48] } \\
\hline & $\mathrm{Mg} \mathrm{N}_{2} \mathrm{O} / \mathrm{ha}$ & -0.02 & Prairie grass to cropland & [48] & \\
\hline & $\mathrm{Mg} \mathrm{NO}_{3} / \mathrm{ha}$ & -4.6 & Prairie grass to cropland & [48] & \\
\hline \multirow{13}{*}{ Rapeseed } & $\mathrm{Mg} \mathrm{CO}_{2} / \mathrm{ha}$ & -88 & Set-aside to cropland DK & [48] & \multirow{13}{*}[48]{} \\
\hline & $\mathrm{Mg} \mathrm{N}_{2} \mathrm{O} / \mathrm{ha}$ & -0.022 & Set-aside to cropland DK & [48] & \\
\hline & $\mathrm{Mg} \mathrm{NO}_{3} / \mathrm{ha}$ & -4.6 & Set-aside to cropland DK & [48] & \\
\hline & $\mathrm{Mg}$ C/ha/y & -0.634 & Broadleaved forest to OSR & [45] & \\
\hline & $\mathrm{Mg}$ C/ha/y & -0.115 & Winter wheat to oilseed rape & [45] & \\
\hline & $\mathrm{Mg} \mathrm{C/ha/y}$ & -0.634 & Grassland to oilseed rape & [45] & \\
\hline & Mg C/ha & -9 & Set-aside to cropland & [50] & \\
\hline & $\mathrm{Mg}$ C/ha & -9 & Temperate grassland to cropland & [50] & \\
\hline & Mg C/ha & -13 & Temperate forest to cropland & [50] & \\
\hline & Mg C/ha & na & Tropical grassland to cropland & [50] & \\
\hline & Mg C/ha & na & Tropical moist rain to cropland & [50] & \\
\hline & $\mathrm{Mg} \mathrm{C} / \mathrm{ha} / \mathrm{y}$ & -0.24 & Straw ploughed back to soil & [51] & \\
\hline & $\mathrm{Mg}$ C/ha/y & -0.4 & Straw not ploughed back to soil & [51] & \\
\hline \multirow{3}{*}{ Mischantus } & $\mathrm{Mg}$ C/ha/y & 0.62 & dLUC (UK) for rapeseed and SRC & [51] & \multirow{3}{*}{ r } \\
\hline & Mg C/ha/y & 0.115 & winter wheat to mischantus & [45] & \\
\hline & $\mathrm{Mg} \mathrm{C/ha/y}$ & 0 & Grassland/broadleaved forest to SRC & [45] & \\
\hline \multirow{3}{*}{ Willow (SRC) } & $\mathrm{Mg}$ C/ha/y & 0.14 & dLUC (UK) for rapeseed and SRC & [51] & \multirow{3}{*}{45} \\
\hline & $\mathrm{Mg} \mathrm{C} / \mathrm{ha} / \mathrm{y}$ & 0.12 & Winter wheat to SRC & [45] & \\
\hline & $\mathrm{Mg}$ C/ha/y & 0.00 & Grassland/broadleaved forest to SRC & [45] & \\
\hline \multirow{4}{*}{ Salix } & $\mathrm{Mg}$ C/ha/y & 0.34 & Fertilized & {$[52]$} & \\
\hline & $\mathrm{Mg}$ C/ha/y & 0.22 & Not fertilized & [52] & \\
\hline & $\mathrm{Mg} \mathrm{N}-\mathrm{N}_{2} \mathrm{O} / \mathrm{ha} / \mathrm{y}$ & 1.15 & Fertilized & [52] & \\
\hline & $\mathrm{Mg} \mathrm{N}-\mathrm{N}_{2} \mathrm{O} / \mathrm{ha} / \mathrm{y}$ & 0.57 & Not fertilized & [52] & \\
\hline \multirow{4}{*}{ Populus } & $\mathrm{Mg}$ C/ha/y & 0.53 & Fertilized & [52] & \\
\hline & $\mathrm{Mg}$ C/ha/y & 0.23 & Not fertilized & [52] & \\
\hline & $\mathrm{Mg} \mathrm{N}-\mathrm{N}_{2} \mathrm{O} / \mathrm{ha} / \mathrm{y}$ & 1.99 & Fertilized & {$[52]$} & \\
\hline & $\mathrm{Mg} \mathrm{N}-\mathrm{N}_{2} \mathrm{O} / \mathrm{ha} / \mathrm{y}$ & 0.5 & Not fertilized & [52] & \\
\hline
\end{tabular}

\section{SI.4 Management of agricultural and biomass conversion residuals}

The removal of straw from fields induces changes in the soil carbon stock [50,53-55]. A depletion of $0.3 \mathrm{Mg} \mathrm{C} / \mathrm{ha}$ of soil organic carbon (SOC) due to straw removal was assumed according to the IPCC carbon tool (Country: Denmark; climate region: cold temperate, moist; 
native soil type: high clay activity mineral; land use type: long-term cultivated, full tillage, from medium to low input). The average straw yield in Denmark for the years 2006-2008 was 3.246 $\mathrm{Mg} / \mathrm{ha}$. As a consequence, the calculated carbon depletion was 0.09 Mg C/Mg straw. Removal of nutrients ( $\mathrm{N}, \mathrm{P}$ and $\mathrm{K}$ ) with the straw led to additional fertilizer use to maintain constant crops yields. The following values were assumed: $6.5 \mathrm{~kg} \mathrm{~N}, 3.4 \mathrm{~kg} \mathrm{P}$ and $2.8 \mathrm{~kg} \mathrm{~K}$ per $\mathrm{Mg} \mathrm{DM}$ straw according to [50]. Straw removal also caused lower $\mathrm{N}_{2} \mathrm{O}$ emissions: a decrease of $0.03 \mathrm{kgN}-$ $\mathrm{N}_{2} \mathrm{O} / \mathrm{Mg}$ DM straw was assumed [50].

The use of grass for energy instead of feeding induced an increased demand for other types of fodder. This was modeled with additional production of barley in order to satisfy the feed demand.

The use on land of digestate from anaerobic digestion of manure was credited by substitution of inorganic N, P, K fertilizers [17,18]: $1 \mathrm{Mg}$ of digestate was assumed to substitute $4.07 \mathrm{~kg}$ of ammonium nitrate (as $\mathrm{N}$ ), $2.1 \mathrm{~kg}$ of triple superphosphate (as $\mathrm{P}_{2} \mathrm{O}_{5}$ ) and $3.3 \mathrm{~kg}$ of potassium chloride (as $\mathrm{K}_{2} \mathrm{O}$ ). The higher amount of $\mathrm{N}$ substituted (compared to direct application on land of raw manure) was a consequence of the higher availability of $\mathrm{N}$ in the digestate after the considered manure treatment (under the assumption that all manure was pig-manure). This has been thoroughly discussed in $[17,18]$.

The use on land of biochar was also credited for its potential positive effects on soil, e.g. carbon sequestration, improved fertilizer efficiency and reduced $\mathrm{N}_{2} \mathrm{O}$ emissions. Based on [56], the content of carbon in the biochar resulting from pyrolysis processes of lignocellulosic materials corresponded to approximately 65\% (wt) and the content of stable carbon (i.e. carbon with a residence time in the soil higher than 1000 years) 54\% (wt). In gasification processes the carbon content in biochar is much lower due to the higher process temperatures. Carbon conversion efficiencies (CCE) of approximately 80\% was reported for lignocellulosic biomass by $[11,12,14,35]$. The remaining $20 \%$ was then found in the biochar. Based on these data, the content of carbon and stable carbon in the biochar from gasification of lignocellulosic was estimated to respectively $45 \%$ and $36 \%$ (wt). This led to a sequestration of carbon with the biochar applied on soil equal to $360 \mathrm{~kg} \mathrm{C} / \mathrm{Mg}$ biochar. Based on [56], the application of biochar also caused an improved efficiency (by 7.2\%) of the applied fertilizers. This, assuming an application rate of biochar of $5 \mathrm{Mg} \mathrm{C} / \mathrm{ha}$ (as stable carbon), and assuming a typical application rate (for corn) of $154 \mathrm{~kg} \mathrm{~N}$ (ammonium nitrate), $64 \mathrm{~kg} \mathrm{P}_{2} \mathrm{O}_{5}$ and $94 \mathrm{~kg} \mathrm{~K}_{2} \mathrm{O}$, resulted in less use 
of ammonium nitrate (3.6 kg N/Mg biochar), triple superphosphate (1.5 $\mathrm{kg}_{2} \mathrm{O}_{5} / \mathrm{Mg}$ biochar) and potassium chloride (2.2 $\mathrm{kg} \mathrm{K} \mathrm{K}_{2} \mathrm{O} / \mathrm{Mg}$ biochar). Also, the lower use of fertilizers further led to decreased emission of $\mathrm{N}_{2} \mathrm{O}$ by $50 \%\left(0.394 \mathrm{~kg} \mathrm{~N}-\mathrm{N}_{2} \mathrm{O} / \mathrm{Mg}\right.$ biochar) [56]. Since these estimations are associated with a high degree of uncertainty (especially in relation to the carbon residual in the biochar and to the possibility of using at all this specific residue on land), in the sensitivity analysis the selected energy scenarios were assessed under the assumption of "no benefits on GW" associated with the management of the biochar. 


\section{References}

[1] U. Jørgensen, P. Sørensen, A.P. Adamsen, I.T. Kristensen, Energi fra biomasse - Ressourcer og teknologier vurderet i et regionalt perspektiv. Aahrus (Denmark): University of Aarhus (2008).

[2] B.V. Mathiesen, H. Lund, K. Karlsson, 100\% Renewable energy systems, climate mitigation and economic growth, Appl. Energy 88 (2011) 488-501.

[3] B.V. Mathiesen, H. Lund, K. Karlsson, IDAs Klimaplan 2050, baggrundsrapport - Tekniske systemanalyser, brændselsforbrug, drivhusgasser, samfund søkonomiske konsekvenser, erhvervspotentialer, beskæftigelseseffekter samt helbredsomkostninger (IDAs Climate Plan 2050, background report in Danish and English). Copenhagen (Denmark): Danish Society of Engineers (IDA, Ingeniørforeningen Danmark) (2009)

[4] H. Lund, B.V. Mathiesen, Energy system analysis of 100\% renewable energy systems: The case of Denmark in years 2030 and 2050, Energy 34 (2009) 524-531.

[5] I. Callesen, P.E. Grohnheit, H. Oesterga, Optimization of bioenergy yield from cultivated land in Denmark, Biomass \& bioenergy 34 (2010) 1348-1362.

[6] C. Boehmel, I. Lewandowski, W. Claupein, Comparing annual and perennial energy cropping systems with different management intensities, Agricultural Systems 96 (2008) 224236.

[7] Ministeriet for foedevarer Landbrug og Fiskeri (Ministry of food Agriculture and Fisheries), Jorden - en knap Ressource. Copenhagen (Denmark): Ministeriet for foedevarer Landbrug og Fiskeri (Ministry of food Agriculture and Fisheries) (2008).

[8] Danish Energy Agency (DEA), Energistatistik 2009. Copenhagen (Denmark): Energistyrelsen (Danish Energy Agency) (2010).

[9] H. Lund, Renewable energy strategies for sustainable development, Energy 32 (2007) 912919.

[10] R.P.J.M. Raven, K.H. Gregersen, Biogas plants in Denmark: successes and setbacks, Renewable \& sustainable energy reviews 11 (2007) 116-132.

[11] U. Arena, F. Di Gregorio, C. Amorese, M.L. Mastellone, A techno-economic comparison of fluidized bed gasification of two mixed plastic wastes, WM (2011).

[12] J. Ahrenfeldt, U. Henriksen, T.K. Jensen, B. Goebel, L. Wiese, A. Kather, H. Egsgaard, Validation of a continuous combined heat and power (CHP) operation of a two-stage biomass gasifier, Energy \& fuels 20 (2006) 2672-2680. 
[13] M. Puig-Arnavat, J.C. Bruno, A. Coronas, Review and analysis of biomass gasification models, Renewable \& sustainable energy reviews 14 (2010) 2841-2851.

[14] U. Arena, F.D. Gregorio, M. Santonastasi, A Techno-Economic Comparison Between Two Design Configurations for a Small Scale, Biomass-to-Energy Gasification Based System, Chem. Eng. Journal 162 (2010) 590.

[15] P.I.I. Borjesson, Energy analysis of biomass production and transportation, Biomass \& Bioenergy 11 (1996) 305-318.

[16] D.L. Carpenter, R.L. Bain, R.E. Davis, A. Dutta, C.J. Feik, K.R. Gaston, W. Jablonski, S.D. Phillips, M.R. Nimlos, Pilot-Scale Gasification of Corn Stover, Switchgrass, Wheat Straw, and Wood: 1. Parametric Study and Comparison with Literature, Ind Eng Chem Res 49 (2010) 18591871.

[17] L. Hamelin, M. Wesnaes, H. Wenzel, B.M. Petersen, Environmental Consequences of Future Biogas Technologies Based on Separated Slurry, Environ. Sci. Technol. 45 (2011) 58695877.

[18] L. Hamelin, M. Wesnæs, H. Wenzel, B.M. Petersen, Life cycle assessment of biogas from separated slurry, Environmental project 1329. Copenhagen (Denmark): Danish Environmental Protection Agency. Available at: http://www.mst.dk/Publikationer/Publications/2010/07/978-8792668-03-5.htm (accessed January 2011) (2010).

[19] T. Prapaspongsa, P. Christensen, J.H. Schmidt, M. Thrane, LCA of comprehensive pig manure management incorporating integrated technology systems, J. Clean. Prod. 18 (2010) $1413-1422$.

[20] M. Wesnaes, H. Wenzel, Life Cycle Assessment of Slurry Management Technologies, Environmental project 1298, Copenhagen (Denmark): Danish Environmental Protection Agency (2009).

[21] N. Jungbluth, M. Chudacoff, A. Dauriat, F. Dinkel, G. Doka, E.M. Faist, E. Gnansounou, N. Kljun, K. Schleiss, M. Spielmann, C. Stettler, J. Sutter, Life Cycle Inventories of Bioenergy. Uster (Switzerland): Swiss Centre for Life Cycle Inventories, ESU-services, Ecoinvent report No 17 (2007).

[22] C. Bauer, Holzenergie. Villigen (Switzerland): ESU-services, Paul Sherrer Institut, Ecoinvent report No 6 (2007).

[23] T. Fruergaard, T. Astrup, T. Ekvall, Energy use and recovery in waste management and implications for accounting of greenhouse gases and global warming contributions, Waste Manage. Res. 27 (2009) 724-737.

[24] J.H. Schmidt, B.P. Weidema, Shift in the marginal supply of vegetable oil, The international journal of life cycle assessment 13 (2008) 235-239. 
[25] J. Larsen, M. Østergaard Petersen, L. Thirup, H. Wen Li, F. Krogh Iversen, The IBUS Process - Lignocellulosic Bioethanol Close to a Commercial Reality, Chem. Eng. Technol. 31 (2008) 765-772.

[26] N.S. Bentsen, B.J. Thorsen, C. Felby, Energy, feed and land-use balances of refining winter wheat to ethanol, Biofuels, bioproducts \& biorefining 3 (2009) 521-533.

[27] N. Jungbluth, R. Frischknecht, M.F. Emmenegger, R. Steiner, M. Tuchschmid, Life Cycle Assessment of BTL-fuel production: Inventory Analysis, RENEW, Renewable fuels for advanced powertrains;ESU-services Ltd, Del-5.2.7-inventory-final.doc (2007).

[28] BioPress, Dansk BioEnergi, 72. Copenhagen (Denmark): Dansk BioEnergi (2003).

[29] A. Prochnow, M. Heiermann, M. Plochl, B. Linke, C. Idler, T. Amon, P.J. Hobbs, Bioenergy from permanent grassland - A review: 1. Biogas, Bioresour. Technol. 100 (2009) 4931-4944.

[30] Danish Energy Agency (DEA), Technology data for energy plants, Copenhagen (Denmark): Energistyrelsen (Danish Energy Agency) (2010).

[31] H.W. Yu, Z. Samani, A. Hanson, G. Smith, Energy recovery from grass using two-phase anaerobic digestion, Waste Manage. 22 (2002) 1-5.

[32] P.A. Gerin, F. Vliegen, J. Jossart, Energy and CO2 balance of maize and grass as energy crops for anaerobic digestion, Bioresour. Technol. 99 (2008) 2620-2627.

[33] M. Wichern, T. Gehring, K. Fischer, D. Andrade, M. Lubken, K. Koch, A. Gronauer, H. Horn, Monofermentation of grass silage under mesophilic conditions: Measurements and mathematical modeling with ADM 1, Bioresour. Technol. 100 (2009) 1675-1681.

[34] H. Uellendahl, G. Wang, H.B. Moller, U. Jorgensen, I.V. Skiadas, H.N. Gavala, B.K. Ahring, Energy balance and cost-benefit analysis of biogas production from perennial energy crops pretreated by wet oxidation, Water Science and Technology 58 (2008) 1841-1847.

[35] U. Arena, L. Zaccariello, M.L. Mastellone, Fluidized bed gasification of waste-derived fuels, Waste Manage. 30 (2010) 1212-1219.

[36] M.S. Rao, S.P. Singh, M.S. Sodha, A.K. Dubey, M. Shyam, Stoichiometric, mass, energy and exergy balance analysis of countercurrent fixed-bed gasification of post-consumer residues, Biomass \& bioenergy 27 (2004) 155-171.

[37] W. Doherty, A. Reynolds, D. Kennedy, The effect of air preheating in a biomass CFB gasifier using ASPEN Plus simulation, Biomass \& bioenergy 33 (2009) 1158-1167. 
[38] Z.A.B.Z. Alauddin, P. Lahijani, M. Mohammadi, A.R. Mohamed, Gasification of lignocellulosic biomass in fluidized beds for renewable energy development: A review, Renewable \& sustainable energy reviews 14 (2010) 2852-2862.

[39] K.J. Ptasinski, Thermodynamic efficiency of biomass gasification and biofuels conversion, Biofuels, bioproducts \& biorefining 2 (2008) 239-253.

[40] X.T. Li, J.R. Grace, C.J. Lim, A.P. Watkinson, H.P. Chen, J.R. Kim, Biomass gasification in a circulating fluidized bed, Biomass \& bioenergy 26 (2004) 171-193.

[41] Y. Cao, Y. Wang, J.T. Riley, W. Pan, A novel biomass air gasification process for producing tar-free higher heating value fuel gas, Fuel Process Technol 87 (2006) 343-353.

[42] J.D. Bentzen, C. Hindsgaul, U.B. Henriksen, L.H. Soerensen, Straw Gasification in a TwoStage Gasifier, Proceedings of the 12.European Biomass Conference (2002) 577-580.

[43] G. Chen, J. Andries, H. Spliethoff, M. Fang, d.E. van, Biomass gasification integrated with pyrolysis in a circulating fluidised bed, Solar Energy 76 (2004) 345-349.

[44] A. Smolinski, K. Stanczyk, N. Howaniec, Steam gasification of selected energy crops in a fixed bed reactor, Renewable Energy 35 (2010) 397-404.

[45] S.S. Clair, J. Hillier, P. Smith, Estimating the pre-harvest greenhouse gas costs of energy crop production, Biomass \& bioenergy 32 (2008) 442-452.

[46] J.H. Schmidt, System delimitation in agricultural consequential LCA - Outline of methodology and illustrative case study of wheat in Denmark, The international journal of life cycle assessment 13 (2008) 350-364.

[47] B. Weidema, Market information in life cycle assessment. Copenhagen (Denmark): Environmental project 863, Danish Environmental Protection Agency (2003).

[48] J.H. Schmidt, Life cycle assessment of rapeseed oil and palm oil, PhD thesis. Aalborg (Denmark): Aalborg University (2007).

[49] J.H. Schmidt, Comparative life cycle assessment of rapeseed oil and palm oil, Int J Life Cycle Assess 15 (2010) 183-197.

[50] F. Cherubini, S. Ulgiati, Crop residues as raw materials for biorefinery systems - A LCA case study, Appl. Energy 87 (2010) 47-57.

[51] M. Brandao, L.M. i Canals, R. Clift, Soil organic carbon changes in the cultivation of energy crops: Implications for GHG balances and soil quality for use in LCA, Biomass \& bioenergy (2010). 
[52] H.J. Hellebrand, M. Strahle, V. Scholz, J. Kern, Soil carbon, soil nitrate, and soil emissions of nitrous oxide during cultivation of energy crops, Nutr Cycl Agroecosyst 87 (2010) 175-186.

[53] B.B. Gabrielle, N. Gagnaire, Life-cycle assessment of straw use in bio-ethanol production: A case study based on biophysical modelling, Biomass \& bioenergy 32 (2008) 431-441.

[54] R.L. Lemke, A.J. VandenBygaart, C.A. Campbell, G.P. Lafond, B. Grant, Crop residue removal and fertilizer $\mathrm{N}$ : Effects on soil organic carbon in a long-term crop rotation experiment on a Udic Boroll, Agriculture, ecosystems \& environment 135 (2010).

[55] W.W. Wilhelm, J.M.F. Johnson, J.L. Hatfield, W.B. Voorhees, D.R. Linden, Crop and soil productivity response to corn residue removal: A literature review, Agron. J. 96 (2004) 1-17.

[56] K.G. Roberts, B.A. Gloy, S. Joseph, N.R. Scott, J. Lehmann, Life Cycle Assessment of Biochar Systems: Estimating the Energetic, Economic, and Climate Change Potential, Environ. Sci. Technol. 44 (2010) 827-833. 